\title{
Effect of Ce-doped bioactive glass/collagen/ chitosan nanocomposite scaffolds on the cell morphology and proliferation of rabbit's bone marrow mesenchymal stem cells-derived osteogenic cells
}

Hanan F. Hammouda ${ }^{1}$, Mohammad M. Farag ${ }^{2 *}$, Mervat M. F. El Deftar ${ }^{3}$, M. Abdel-Gabbar ${ }^{4}$ and Basant M. Mohamed ${ }^{4}$

\begin{abstract}
Background: Cerium-containing materials have wide applications in the biomedical field, because of the mimetic catalytic activities of cerium. The study aims to deeply estimate the biocompatibility of different scaffolds based on Ce-doped nanobioactive glass, collagen, and chitosan using the first passage of rabbit bone marrow mesenchymal stem cells (BM-MSCs) directed to osteogenic lineage by direct and indirect approach. One percentage of glass filler was used (30 wt. \%) in the scaffold, while the percentage of $\mathrm{CeO}_{2}$ in the glass was ranged from 0 to $10 \mathrm{~mol}$. \%. Cytotoxicity was evaluated by monitoring of cell morphological changes and reduction in cell proliferation activity of BMMSCs maintained under osteogenic condition using proliferation assays, MTT assay for the direct contact of cells/ scaffolds twice in a week, trypan blue and hemocytometer cell counting for indirect contact of cells/scaffolds extracts at day 7. Cell behaviors growth, morphology characteristics were monitored daily under a microscope and cell counting were conducted after 1 week of the incubation of the cells with the extracts of the four composite scaffolds in the osteogenic medium at the end of the week.
\end{abstract}

Results: Showed that at $24 \mathrm{~h}$ after direct contact with composite scaffold, all scaffolds showed proliferation of cells $>$ $50 \%$ and increased in cell density on day 7. The scaffold of the highest percentage of $\mathrm{CeO}_{2}$ in bioactive glass nanoparticles (sample $\mathrm{CL} / \mathrm{CH} / \mathrm{C} 10)$ showed the lowest inhibition of cell proliferation $(<25 \%)$ at day 7 . Moreover, the indirect cell viability test showed that all extracts from the four composite scaffolds did not demonstrate a toxic effect on the cells (inhibition value $<25 \%$ ).

Conclusion: The addition of $\mathrm{CeO}_{2}$ to the glass composition improved the biocompatibility of the composite scaffold for the proliferation of rabbit bone marrow mesenchymal stem cells directed to osteogenic lineage.

Keywords: Nanobioactive glass, Cerium, Chitosan, Collagen, Scaffold, Mesenchymal stem cells, Osteogensis

*Correspondence: mmfaragnrc@gmail.com

${ }^{2}$ Glass Research Department, National Research Centre, 33 El Bohouth

Str., Dokki, Giza 12622, Egypt

Full list of author information is available at the end of the article

\section{Background}

Fabricated scaffold acting as a temporary substitute for bone defects is still under investigation, and so far the scientists have not been able to get an ideal scaffold that overcomes all problems associated with the traditional methods of bone surgery by bone-graft substitutes like 
morbidity of the donor site and limitation in the amount of bone available and surgical cost for the harvesting procedure also, are highly associated to the risk of rejection, infection, contamination, pain at the harvest site, bleeding hematoma, and disease transfer [1-3], lack of osteogenicity and most of them lack osteoconductivity as implant materials of low biocompatibility such as copper, silver, and bone cement shows little or no osteoconduction, while other carry hazards of viral transmission and other implants like metals would release harmful ions and increase the risk of cancer $[4,5]$. The ideal scaffold should be biocompatible, i.e., non-immunogenic and non-toxic to be in contact with the living system without producing an adverse effect that might reduce healing or cause rejection by the body [6].

Recently, the intensity of research on hybrid or composite scaffolds is rapidly increasing, especially in the field of tissue engineering. These composite materials have been developed to combine different material properties to overcome some drawbacks related to some materials and obstacles to their use in important applications.

Based on the literature, composite scaffolds used in tissue engineering applications are either synthetic or naturally derived polymers. Natural polymers attracted the attention of researchers toward the development of suitable biocompatible composite scaffolds for use in bone tissue regeneration. This is due to natural polymers being more available, superabundant, and similar to the extracellular matrix components. Collagen is the major constituent of natural bone and has dual properties in the bioactivity as well as in the biomimetic property. It offers many binding sites for cell attachment, increasing the growth and proliferation of cells, as reported in several studies $[7,8]$. However, the low mechanical strength and osteoinductivity of collagen limit its wider applications in the bone regeneration field. By incorporating different biomaterial's, the properties such as porosity, structural stability, osteoinductivity, and osteogenicity of collagen matrixes can be largely improved [9].

Chitosan is another type of natural polymer derived from renewable marine resources and industries from the chitin of crustaceans and fungal mycelia. It is a semicrystalline polysaccharide polymer. It is composed of $\mathrm{N}$-acetyl D-glucosamine and D-glucosamine units [10, 11]. Bioactive compounds as well as bioresorbable materials, which can mimic the natural function of bone and activate in vivo mechanisms for bone regeneration. They can be easily functionalized to enhance bone mineralization [12]. Moreover, the favorable properties, such as biodegradability, mucoadhesion, hemostatic activity, its antibacterial and antifungal activities, cell compatibility, and limited immunogenicity $[10,11]$, directed this polymer to be widely used in different biomedical applications. However, chitosan-based scaffolds have limitations in terms of mechanical strength and osteoconductivity hinders its application in bone tissue engineering. To overcome these limitations, chitosan has been blended with a variety of materials that include (natural and synthetic) polymer, ceramics, and other additives [13].

The combination of two or more polymers allows to develop new biomaterials that exhibit combinations of properties that could not be obtained from individual polymers [14]. Therefore, there have been numerous studies that used chitosan and collagen to fabricate scaffolds for skin regeneration [15-17] and vascular regeneration [18-20].

For bone regeneration, polymer-ceramic composites are considered an advanced class of biomaterial's that are more optimal for bone scaffolding applications due to the biodegradable polymers that are usually not bioactive; therefore, incorporation of bioactive materials into these biodegradable polymers combines between the bioactivity property, which comes from the bioactive materials and gains the flexibility characteristic which comes from the polymer [21, 22]. The bioactive glasses are amorphous materials (usually based on silica) that are biocompatible, bioactive, osteoconductive, and even osteoproductive, that comes from their unique ability to convert to hydroxyapatite in vivo, and their capability to bond with the bone and soft tissues [23-25] which recommended them as very suitable filler for biopolymers matrices [26, 27]. Moreover, bioactive glasses are characterized by a possibility to incorporate therapeutic ions (e.g., $\mathrm{Li}, \mathrm{Ag}, \mathrm{Cu}$, and $\mathrm{Ce}$ ). Cerium is one of the potential therapeutic ions added to bioactive glasses. It can protect the cells from damage created by the reactive oxygen species (ROS) which resulted from normal oxygen metabolism [28]. That is due to their ability to switch the oxidation states between $\mathrm{Ce}^{4+}$ and $\mathrm{Ce}^{3+}[29]$. This nominated their compounds, such as nanoceria, to be used in the treatment of several diseases and disorders, including cardiovascular disease, Parkinson's and Alzheimer's disease, and even tumor development [30]. Thus, cerium has been incorporated in numerous bioactive glasses to improve their functionality for the treatment of several diseases [31-41].

In order to improve and accelerate the bone healing process, the involvement of mesenchymal stem cells (MSCs) with bone composite scaffold is critical, MSCs are multipotent stromal stem cells that can be harvested from many different sources and differentiated into different lineages such as adipogenic, chondrogenic, and osteogenic; however, aging, senescence, and oxidative stress reduce their ex vivo expansion, which is critical for their clinical applications. Therefore, 
there is a great need to identify methods to manipulate MSCs to reduce ROS in both the MSCs themselves during their culture expansion production phase and in the injured tissue microenvironment to promote MSC engraftment and enhance tissue repair. It has been reported that antioxidants stimulate MSC proliferation [42]. Concerning the osteogenesis process, numerous studies point to ROS inhibiting osteogenic differentiation [43]. In MSCs, excess ROS or exogenous addition of $\mathrm{H}_{2} \mathrm{O}_{2}$ can weaken self-renewal, differentiation capacity, and proliferation [44-46] especially that MSCs are rare cells; they constitute only 0.001 to $0.01 \%$ of the bone marrow population. Since regeneration of large tissues requires around $10^{7}$ to $10^{8} \mathrm{MSCs}$ [47], there exists a need for MSCs to be expanded prior to tissue regeneration. Several passages in vitro decrease the life span of cells, as their longevity and functions are affected by oxidative stress; hence, antioxidants stimulate MSC proliferation [42]. The idea is that ROS and oxidative stress must decrease to allow for osteogenic differentiation to implement.

Accordingly, incorporation of Ce-containing bioactive glasses in biodegradable polymer scaffolds increases the impact and value of these scaffolds for tissue engineering applications, and there have been several studies that used bioactive glasses doped with cerium as bioactive fillers in polymer scaffolds [48-51]. Biocompatibility testing became an important step toward animal testing and finally clinical trials that will determine the biocompatibility of the material in a given application, and thus medical devices, like implants or any other stimulating delivery devices, such as proteins, genes, and drugs [52]. The biocompatibility testing contains numerous in vitro tests that are used following ISO (10993) or other standards as defined by IUPAC [53] qualitatively by the direct contact and quantitatively by MTT assay.

This work aims to fabricate suitable biocompatible composite scaffolds based on collagen and chitosan polymer blend used as a polymer matrix for nanobioactive glass doped with different ratios of $\mathrm{CeO}_{2}$ next to study the morphological and microstructural characterization of those scaffolds to know whether they will facilitate the proliferation of BMMSCs directed to osteogenic lineage to be used for basic research studies and future tissue engineering purposes. According to our knowledge, there have not much data about the biocompatibility of composite scaffolds based on collagen and chitosan polymer blend used as a polymer matrix for nanobioactive glass doped with different ratios of $\mathrm{CeO}_{2}$. In vitro biocompatibility test was performed by evaluating cell morphology and measuring cell viability by the direct contact of the BMMSCs directed to osteogenic lineage around or in the vicinity of the scaffold surfaces and by the indirect test using the fluid extracts of these scaffolds for the proliferation of cells.

\section{Methods}

Preparation of nanobioactive glasses (NBGs) and scaffolds Different nanobioactive glasses were synthesized based on (80-x) $\mathrm{SiO}_{2}-15 \mathrm{CaO}-5 \mathrm{P}_{2} \mathrm{O}_{5}-\mathrm{xCe}_{2} \mathrm{O}$, in mole $\%(x=0$, 5 , and 10 mole \%); accordingly, the glass was encoded as BG-C0, BG-C5, and BG-C10, respectively (Table 1). The glasses were prepared by a quick alkali-mediated sol-gel method [54]. Briefly, TEOS was added to EtOH solution and then $2 \mathrm{M} \mathrm{HNO}_{3}$ was added, the molar ratio of TEOS: H2O: EtOH was 1:8:10. Subsequently, TEP, $\mathrm{Ca}\left(\mathrm{NO}_{3}\right)_{2} \cdot 4 \mathrm{H}_{2} \mathrm{O}$, and ammonium cerium (IV) nitrate were added, respectively, after complete hydrolysis of TEOS, with 20 min time interval, and the solution left to stir for $3 \mathrm{~h}$. The sol was subjected to quick gelling using a concentrated ammonia solution. The resulted gel was dried at $60{ }^{\circ} \mathrm{C}$ for 2 days and ultimately it was transformed to glass by calcination at $600{ }^{\circ} \mathrm{C}$ in the air for 30 min. The obtained glass particles were used subsequently in preparation of composite scaffolds.

The scaffolds used in this study were prepared based on collagen and chitosan, with 1:1 volume ratio, as a polymer matrix, and the glass was added to the scaffold with $30 \mathrm{wt} . \%$. Typically, $2 \%(\mathrm{w} / \mathrm{v})$ of chitosan was dissolved in $1 \%(\mathrm{v} / \mathrm{v})$ acetic acid. An equal volume of chitosan solution and as-prepared collagen solution was mixed well, and the glass particles were added to this mixture and stirred for $3 \mathrm{~h}$ and put in the ultrasonic bath for $30 \mathrm{~min}$ to assure dispersion of glass particles in the polymer matrix. And then, the mixture was frozen at $-20{ }^{\circ} \mathrm{C}$ for 2 days and lyophilized thereafter at $-50{ }^{\circ} \mathrm{C}$ for 2 days to obtain the final scaffold [55]. The collagen/chitosan, collagen/chitosan/C0, collagen/chitosan/C5 and collagen/ chitosan/C10 scaffolds encoded as $\mathrm{CL} / \mathrm{CH}, \mathrm{CL} / \mathrm{CH} / \mathrm{C} 0$, $\mathrm{CL} / \mathrm{CH} / \mathrm{C} 5$, and $\mathrm{CL} / \mathrm{CH} / \mathrm{C} 10$ samples, respectively.

\section{Characterization of nanobioactive glass and derived scaffolds}

Bioactive glass nanoparticles were characterized by DTA (differential thermal analysis) by using Setaram, in the temperature range $25-800{ }^{\circ} \mathrm{C}$ with a rate of 10 ${ }^{\circ} \mathrm{C} . \mathrm{min}^{-1}$ to determine the thermal behavior of the dry

Table 1 Glass composition in mole \%

\begin{tabular}{lllll}
\hline & $\mathrm{SiO}_{\mathbf{2}}$ & $\mathrm{CaO}$ & $\mathbf{P}_{\mathbf{2}} \mathbf{O}_{\mathbf{5}}$ & $\mathbf{C e O}_{\mathbf{2}}$ \\
\hline $\mathrm{C} 0$ & 80 & 15 & 5 & 0 \\
$\mathrm{C} 5$ & 75 & 15 & 5 & 5 \\
$\mathrm{C} 10$ & 70 & 15 & 5 & 10 \\
\hline
\end{tabular}


gels. A transmission electron microscope (TEM, model; JEM2010, Japan) working at $100 \mathrm{kV}$, was used to investigate the morphology and particle size. Furthermore, Fourier transform infrared (FTIR) technique was used to detect the characteristic vibration modes in the wavenumber range of $4000-400 \mathrm{~cm}^{-1}$ by using JASCO FT/ IR-4600.

The morphological and microstructural characterizations of the scaffolds were examined by SEM/EDX (model, HITATCHI Su800). Scanning electron microscopy (SEM) on the gold-coated specimen was used to examine the morphological and textural features of the sample, using an accelerating voltage of $15 \mathrm{kV}$. Before scanning, discs were sectioned with a very sharp scalpel in order to expose their internal (cross-sectional) microstructure. Sectioning was necessary because the surfaces of the external disc exhibited much smoother architecture than their internal parts.

\section{In vitro biocompatibility test Cell isolation}

The osteoblast-like cells were obtained from bone marrow mesenchymal stem cells (BM-MSCs) isolated from the femurs and tibia of six rabbits with an (average age: $6-8$ weeks and average weight: $0.75-1 \mathrm{~kg}$ ). The rabbits were sacrificed without complication to animals by cervical dislocation in the animal house lab using the guidelines approved by the Medical Research Ethics Committee on the Use of Animal Subjects at National Cancer Institute, Cairo, and approved by the Ethics Research Committee of the Faculty of Science, Beni-Suef University, Beni-Suef, Egypt (Ethics approval number: 021-194). Figure 1 represents the steps of isolation of

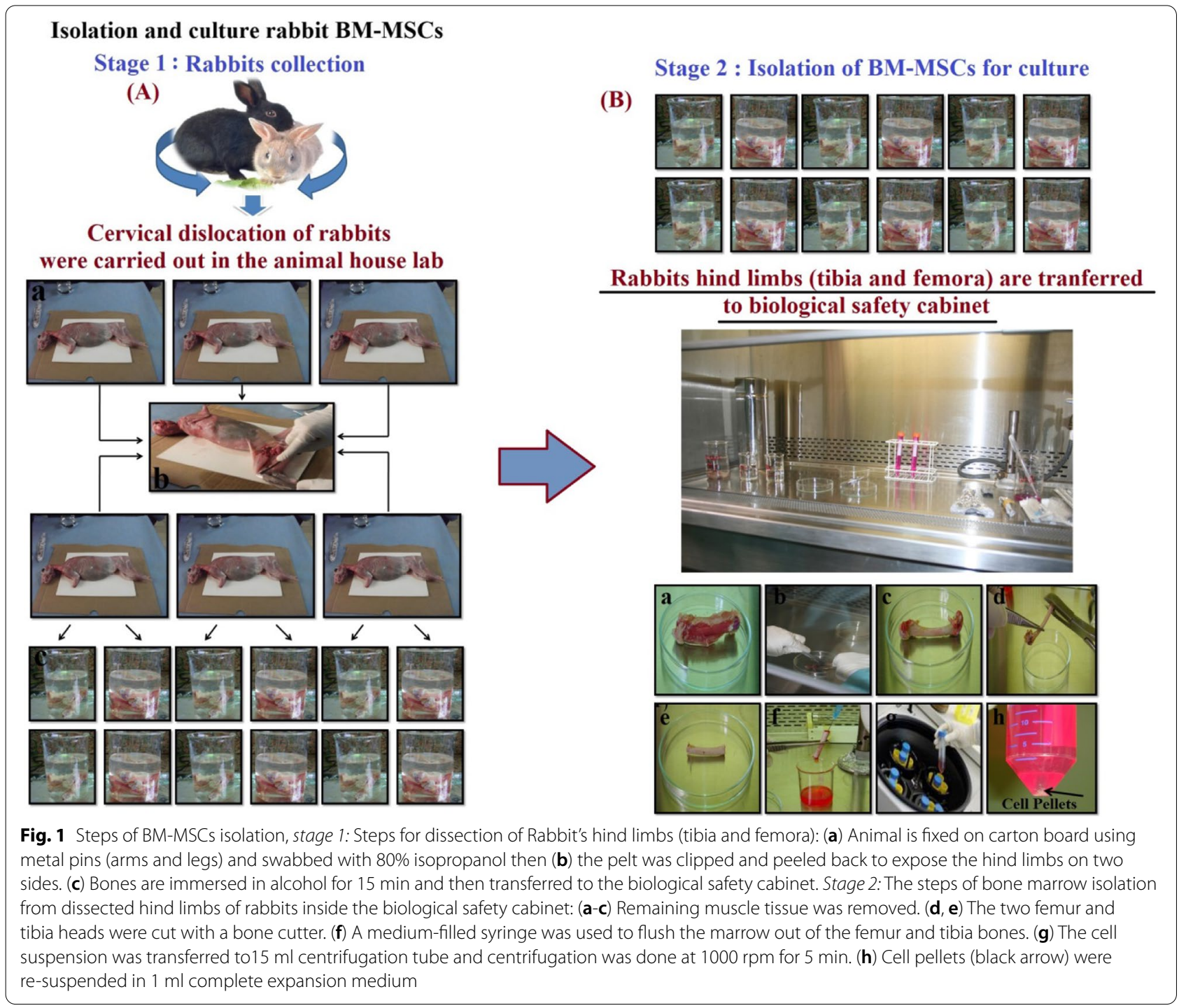


BM-MSCs from the rabbit's hind limbs (tibia and femora). The isolation protocol was performed according to protocols described previously [56-58] on two stages, the first steps (Fig. 1A (a, c)) for dissection of rabbit's hind limbs (tibia and femora) in animal house lab, the animal is a fixed carton board using metal pins (arms and legs) and swabbed with $80 \%$ isopropanol and then the pelt was clipped and peeled back to expose the hind limbs on two sides after that bones are immersed in alcohol for $15 \mathrm{~min}$ after that transferred to the biological safety cabinet. The second step for bone marrow isolation from dissected hind limbs of rabbits inside the biological safety cabinet (Fig. 1B (a-h)). Remaining muscle tissue was removed. The two femur and tibia heads were cut with a bone cutter. A medium-filled syringe was used to flush the marrow out of the femur and tibia bones and then the cell suspension was transferred to a $15 \mathrm{ml}$ centrifugation tube and centrifugation was done at $1000 \mathrm{rpm}$ for $5 \mathrm{~min}$ and finally cell pellets were re-suspended in $1 \mathrm{ml}$ complete expansion medium.

Cell morphology study of the four composite scaffolds (direct contact) and their extracts (indirect contact) was examined using inverted phase contrast microscopes; a qualitative method was used to test the biocompatibility of the material by placing it directly with cultured cells.

Cells were collected and cultured in expansion medium low-glucose DMEM/Ham's F12 (Biochrome, AG) mixture (1:1) supplemented with $10 \%$ fetal bovine serum (Biochrome AG), 10\% basic-Fibroblast growth factor (Sigma), 1\% L-glutamax (Invitrogen, $2 \mathrm{~mm}$ ), 1\% penicillin-streptomycin $(100 \mathrm{U} / \mathrm{ml}-100 \mu \mathrm{g} / \mathrm{ml}$, Lonza), and 0.25 $\mu \mathrm{g}$ fungizone (Lonza) and then incubated in a humidified atmosphere of $5 \% \mathrm{CO}_{2} / 95 \%$ air at $37{ }^{\circ} \mathrm{C}$. The medium was completely exchanged every 3 days till reached to confluence $80 \%$ to $90 \%$. Cells were trypsinized with $0.25 \%$ trypsin (Lonza) and collected by centrifuge and then counted with a hemocytometer and re-plated again as the first passage at a density $5 \times 10^{3}$ cells per $/ \mathrm{cm}^{2}$ in 24 -well culture plates for further expansion and osteogenesis. Cells were maintained in osteogenic medium (the same expansion medium described above plus $50 \mu \mathrm{m}$ L-ascorbic acid 2-phosphate, $100 \mathrm{~nm}$ dexamethasone, and10 mm $\beta$-glycerophosphate (Applichem)) [59].

The reactivity of the four composite scaffolds $(\mathrm{CL} / \mathrm{CH}$, $\mathrm{CL} / \mathrm{CH} / \mathrm{C} 0, \mathrm{CL} / \mathrm{CH} / \mathrm{C} 5$, and $\mathrm{CL} / \mathrm{CH} / \mathrm{C} 10$ ) was indicated by studying cell morphology in the vicinity of scaffold surfaces in culture wells and observing malformation, degeneration, and lysis of cells around the test material in comparison to non-toxic negative control material.

The direct contact was done by seeding the isolated sub-cultured BM-MSCs cells at a density $5 \times 10^{3}$ cells per $/ \mathrm{cm} 2$ in 24-well culture plates, first for 1 day in osteogenic medium and then leaving the cells to settle first by plastic adherence property (specific property for mesenchymal stem cells) after that, we put the gamma rays sterilized composite scaffolds which maintained in the osteogenic cultured medium at least $12 \mathrm{~h}$ before incubation $(\mathrm{CL} / \mathrm{CH}, \mathrm{CL} / \mathrm{CH} / \mathrm{C} 0, \mathrm{CL} / \mathrm{CH} / \mathrm{C} 5$, and $\mathrm{CL} / \mathrm{CH} / \mathrm{C} 10)$ respectively at the corners of well plates not directly on the cells to avoid cells disturbance. Also, we do independent repeatability for each scaffold to be easy to do good analysis. All composite scaffolds were incubated in 24-well culture plates with sub-cultured BM-MSCs for 1 week in a humidified atmosphere of $5 \% \mathrm{CO}_{2} / 95 \%$ air at $37^{\circ} \mathrm{C}$ for 7 days.

The morphology, cell spread, and cell growth were microscopically evaluated daily till day 7 . The scaffolds planned for phase-contrast microscopic examination were originally prepared in very thin sections to give adequate translucency that would allow the light to pass through and then were cut in pieces equal in size $100 \mathrm{mg} /$ $\mathrm{ml}$ and shape using sterile scissors and scalpels.

The cell-seeded scaffolds were directly examined without fixation after $24 \mathrm{~h}$ of culture while they were still in their culture plate. Also, groups of cell/scaffolds were examined by fixation and staining with Giemsa stain after 3 days of culture and day 7. Many pictures of cells were taken at different time points for studying morphological features and the capacity to adhere to plastic plates.

Another hand, a group of cells in the 24 well plates (in triplicate) was left to incubate in the various extract composite scaffolds prepared in the osteogenic medium as described by Zhou and Chen [60]. All the same pieces were immersed in the extracting media $100 \mathrm{mg} / \mathrm{ml}$ preparation of the different extracts. The extract media were the same culture osteogenic medium as described above. The extraction process was carried out in a water bath at $37{ }^{\circ} \mathrm{C}$ in separate four $15 \mathrm{ml}$ falcon tubes and then was shaken at a speed of $60-65 \mathrm{rev} / \mathrm{min}$ for 2 days. The extracts were passed through a $0.22-\mu \mathrm{m}$ filter and then were stored at $-20{ }^{\circ} \mathrm{C}$ till used for at least 1 week.

The four composite scaffold samples and their extract were maintained under the same culture conditions alone without cells besides the tissue culture plastic polystyrene with culture media with cells was used as a non-toxic negative control material and the same four composite scaffolds and their extracts were supplemented with polyvinyl chloride (concentration of 20 and $100 \mathrm{mg} / \mathrm{ml}$ ) in culture medium was used as a positive toxic control material. Both seeded and unseeded were examined daily.

\section{MTT proliferation assay}

The biocompatibility of the four composite scaffolds was assessed colorimetrically by MTT assay [61]. After incubation, the scaffold pieces were removed. The cells were rinsed with PBS to remove non-adhering cells, followed 
by incubation in $50 \mu \mathrm{l}$ MTT reagent $(5 \mathrm{mg} / \mathrm{ml})$ in PBS for $4 \mathrm{~h}$. Formazan crystals formed were dissolved by adding $500 \mu \mathrm{l}$ of DMSO solution to lyse cells and release formazan. The solution $(150 \mu \mathrm{l})$ from each sample was transferred to 96 well-plates, and optical density (O.D) was measured in a BMG LABTECH ${ }^{\circledR}$ - FLUOstar Omega microplate reader (Ortenberg, Germany) at an absorbance of $490 \mathrm{~nm}$ [62]. The tissue culture plastic polystyrene was used as non-toxic negative control material and polyvinylchloride (concentration of 20 and $100 \mathrm{mg} / \mathrm{ml}$ ) was used as the positive toxic control material. Culture plates were incubated in a humidified atmosphere of $5 \%$ $\mathrm{CO}_{2} / 95 \%$ air at $37^{\circ} \mathrm{C}$ and the MTT assay was performed two times at hour 24 and day 7 in triplicate by measuring optical density then evaluating cell growth \% and cell inhibition \% as follows.

$$
\begin{aligned}
& \% \text { Cell growth }(\text { cell viability })=\frac{\text { Absorbance }(\mathrm{O} . \mathrm{D}) \text { of sample }}{\text { Absorbance (O.D) of negative control }} \times 100 \\
& \% \text { Cell inhibition }=100-\% \text { cell growth }
\end{aligned}
$$

Another hand (indirect contact test), we evaluated the reduction in cell proliferation activity of the four composite extracts by the trypan blue exclusion test of cell viability in Neubauer hemacytometer at day 7 in triplicate [63]. The old medium in well culture plates of sample extracts was discarded, and the adherent cells washed with $1 \mathrm{ml}$ of Dulbecco's phosphate-buffered saline without calcium and magnesium (DPBS-A) ions to remove traces of serum presented in the medium. The cells were detached from well plates using $0.25 \%$ trypsin with $0.1 \%$ EDTA thereafter, and then transferred into $15 \mathrm{ml}$ centrifuge tubes and centrifuged at $104 \mathrm{rpm}$ for 5 min. Briefly, cells were re-suspended in PBS containing trypan blue by mixing 1 part of $0.4 \%$ trypan blue and 1 part cell suspension (dilution of cells) and allow the mixture to incubate $\sim 3 \mathrm{~min}$ at room temperature and then were examined in counting chamber of hemacytometer by inverted phase-contrast microscope to determine the percentage of cells that have clear cytoplasm, nonstained (viable cells) versus cells that have blue cytoplasm stained (nonviable cells). The percentage of viable cells was measured as follows:

$$
\text { Viable cells } \%=\frac{\text { Total number of viable cells per } \mathrm{ml} \text { of aliquot }}{\text { Total number of cells per } \mathrm{ml} \text { of aliquot }} \times 100
$$

\section{Statistical analyses}

All experimental data stated in this work were expressed as the average \pm standard deviation (SD) for $n=3$ and were analyzed using standard analysis of the one-way
ANOVA test. The level of significance ( $p$ value) is set at $<0.05$.

\section{Results \\ DTA}

The differential thermal analysis (DTA) of dry gels, C0, $\mathrm{C} 5$, and $\mathrm{C} 10$ are shown in Fig. 2. The first endothermic peaks at $113{ }^{\circ} \mathrm{C}, 127^{\circ} \mathrm{C}$, and $127^{\circ} \mathrm{C}$ for $\mathrm{C} 0, \mathrm{C} 5$, and $\mathrm{C} 10$ (see Table 1), respectively, were assigned to the elimination of adsorbed water from the dry gels [64]. The exothermic peaks observed at $284{ }^{\circ} \mathrm{C}, 284{ }^{\circ} \mathrm{C}$, and $287{ }^{\circ} \mathrm{C}$ for $\mathrm{C} 0, \mathrm{C} 5$, and $\mathrm{C} 10$, respectively, were attributed to the removal of organic species of the starting materials (i.e., alkoxyl groups). Moreover, the second endothermic peaks detected at $507{ }^{\circ} \mathrm{C}, 428^{\circ} \mathrm{C}$, and $443{ }^{\circ} \mathrm{C}$ for $\mathrm{C} 0$, $\mathrm{C} 5$, and $\mathrm{C} 10$, respectively, were attributed to the further removal of organics in addition to the loss of residual nitrates of the precursors, as well as the glass transition temperatures ( $\mathrm{Tg}$ ) [65]. The results showed that the residuals were totally removed before $510{ }^{\circ} \mathrm{C}$ for all samples. Accordingly, the temperature of $600{ }^{\circ} \mathrm{C}$ was selected for the calcination of the as-prepared dry gels to obtain the glass powders. It can be noticed from these results that the addition of $\mathrm{CeO}_{2}$ to the glass was decreased the $\mathrm{Tg}$, this can be explained by disrupting the effect of such oxide on the glass network, and hence the generation of more number of non-binding oxygen in the network [41]. These results were confirmed by FTIR analysis.

\section{TEM}

The morphology and particle size of different glass samples were examined by TEM technique (Fig. 3) shows TEM micrographs of $\mathrm{C} 0, \mathrm{C} 5$, and $\mathrm{C} 10$, respectively. It can be noted from the figure that the particle sizes of all samples were in the nano-scale $(<100 \mathrm{~nm})$ with spherical shapes. Furthermore, and the Ce-substituted glasses (C5 and C10 samples) were obviously smaller than that of Ce-free glass $(\mathrm{C} 0)$. The particle size ranged from 30 to $80 \mathrm{~nm}$ for C0 glass, while it was ranged from 10 to $50 \mathrm{~nm}$ for $\mathrm{C} 5$ and $\mathrm{C} 10$ glasses. Therefore, the substitution of $\mathrm{Ca}$ with Ce in the glass composition caused a decrease in the particle size.

\section{FTIR}

The vibration modes of different units in the glass network of different glass samples were investigated by FTIR as shown in Fig. 4. It can be noted from the figure presence of a peak at $465 \mathrm{~cm}^{-1}$ for all samples, which was attributed to $\mathrm{Si}-\mathrm{O}-\mathrm{Si}$ bending vibration modes [33]. Very weak doublets at 571 and $602 \mathrm{~cm}^{-1}$ were observed clearer in $\mathrm{C} 0$ glass than that of the other two glasses which were assigned to the antisymmetric bending mode of $\mathrm{O}-\mathrm{P}-\mathrm{O}$ in the phosphate groups $\left(\mathrm{PO}_{3}{ }^{-4}\right)$. Moreover, 


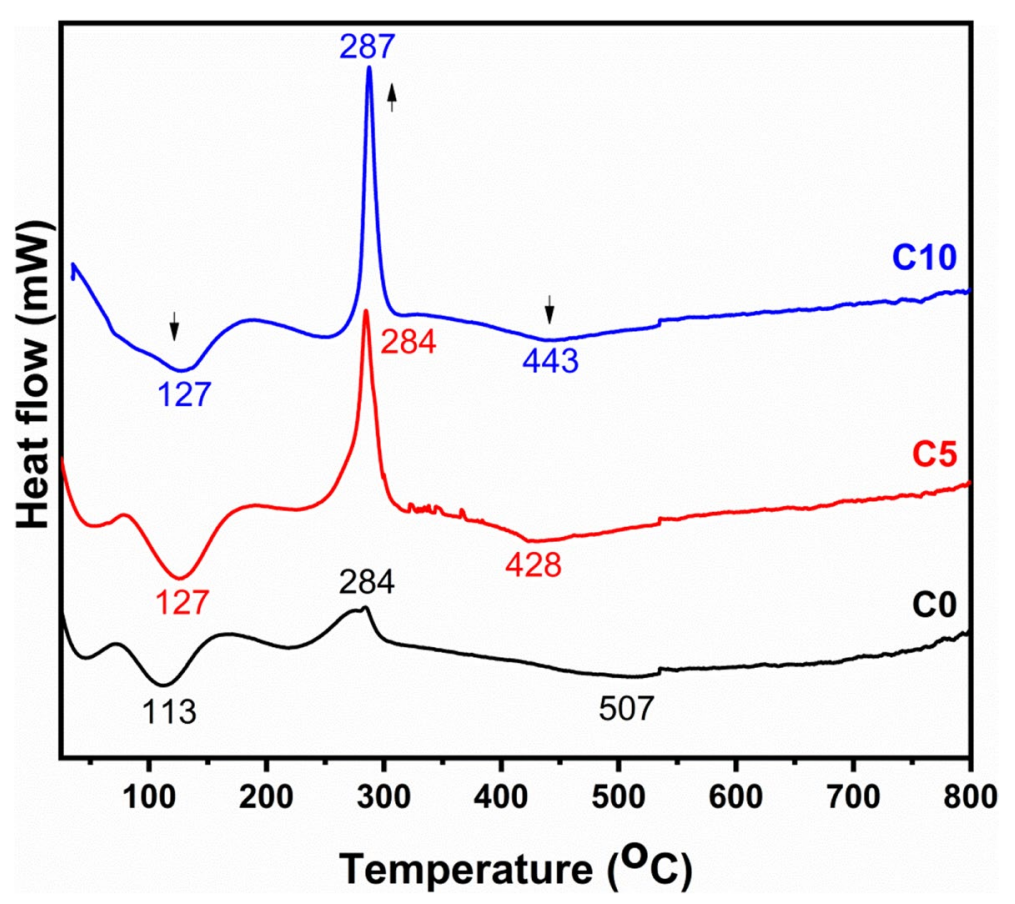

Fig. 2 The differential thermal analysis (DTA) of dry gels, C0, C5, and C10
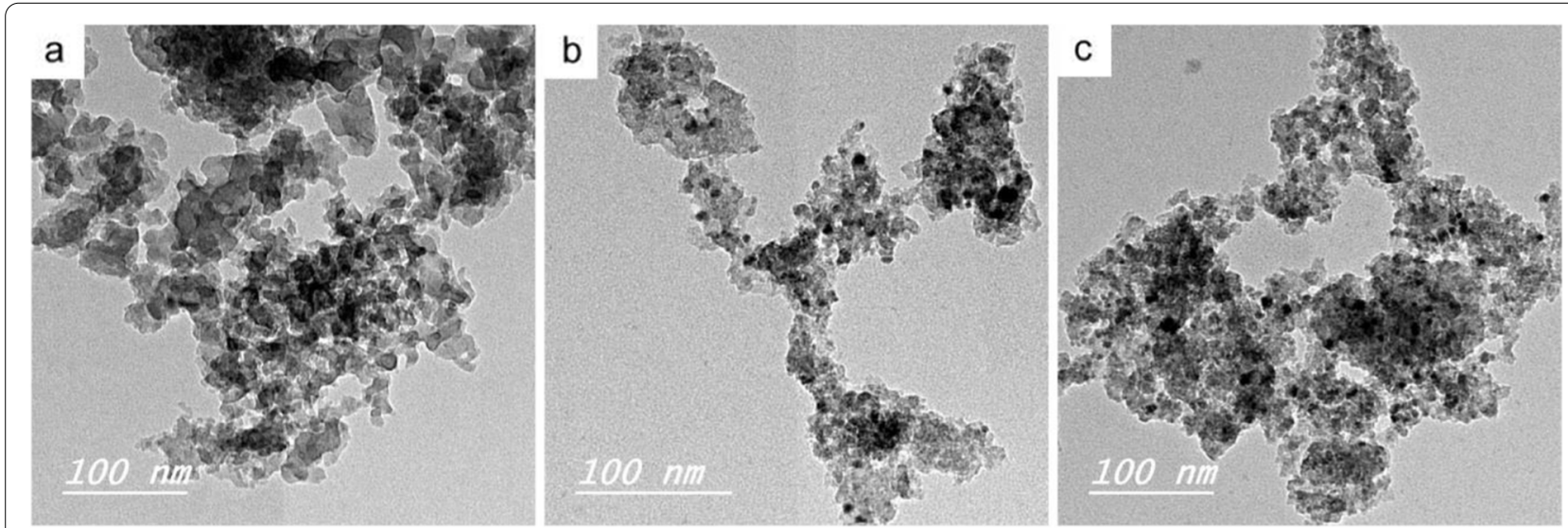

Fig. 3 TEM micrographs of C0, C5, and C10 glasses ( $\mathbf{a}, \mathbf{b}$, and $\mathbf{c}$, respectively)

O-Si-O bending mode of orthosilicate $\mathrm{SiO}_{4}{ }^{4-}$ was located at $803 \mathrm{~cm}^{-1}$ [66]. The shoulder detected at $956 \mathrm{~cm}^{-1}$ was assigned to $\mathrm{Si}-\mathrm{O}-\mathrm{NBO}$ stretching [67]. It was stronger in $\mathrm{C} 5$ and $\mathrm{C} 10$ than in $\mathrm{C} 0$, which indicated that the addition of $\mathrm{CeO}_{2}$ at expense of $\mathrm{CaO}$ disrupted the silicate glass network and increased NBOs throughout the network [68]. The presence of a large number of NBOs increases the reactivity of the glass surface in the biological fluid and hence stimulates apatite formation with the surrounding tissues [69]. The $\mathrm{Si}-\mathrm{O}-\mathrm{Si}$ asymmetric stretching vibration mode was noted at $1101 \mathrm{~cm}^{-1}$ for $\mathrm{C} 0$ sample and $1081 \mathrm{~cm}^{-1}$ for $\mathrm{C} 5$ and $\mathrm{C} 10$ glasses [33]. Accordingly, $\mathrm{CeO}_{2}$ shifted this band toward the lower value, because it weakened the glass network. Finally, the broad shoulder noticed at about $1215 \mathrm{~cm}^{-1}$ was assigned to $\mathrm{Si}-\mathrm{O}-\mathrm{Si}$ bending mode [70].

\section{Composite scaffolds morphology}

Different composite scaffolds based on collagen, chitosan, and/or nano-bioactive glass (NBG) were prepared by the thermal-induced phase separation method, and the cross-section of these scaffolds was examined 


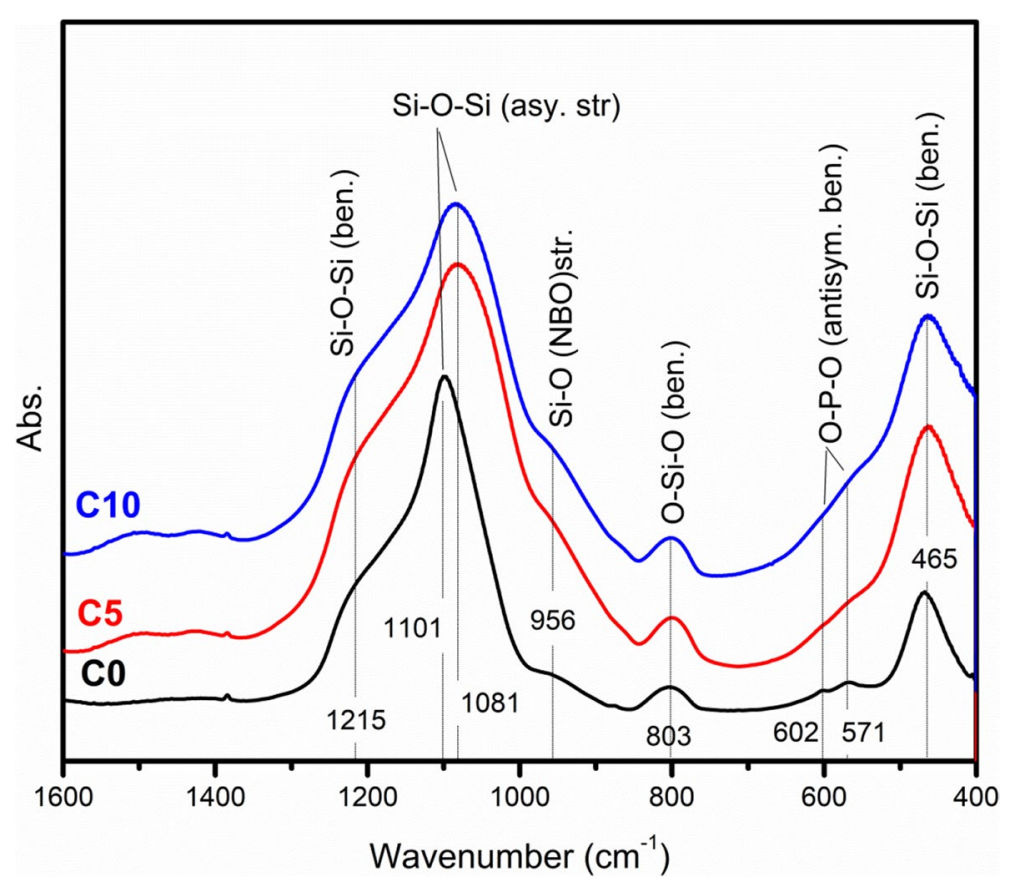

Fig. 4 FTIR of the vibration modes of $\mathrm{CO}, \mathrm{C} 5$, and $\mathrm{C} 10$ glasses

by SEM technique. Figure 5 shows SEM micrographs of $\mathrm{CL} / \mathrm{CH}, \mathrm{CL} / \mathrm{CH} / \mathrm{CO}, \mathrm{CL} / \mathrm{CH} / \mathrm{C} 5$, and $\mathrm{CL} / \mathrm{CH} / \mathrm{C} 10$ scaffolds. From the figure, it can be noticed that all scaffolds were characterized by macroporous and interconnected porous structures. On the other hand, the neat collagen/ chitosan scaffold (sample $\mathrm{CL} / \mathrm{CH}$ ) possessed a circular and relatively large pore size $(50-300 \mu \mathrm{m})$, while the scaffolds that contained bioactive glass fillers were characterized by elongated and a relatively small pore size. Moreover, the figure showed a well-distribution of glass particles in the polymer matrix. Accordingly, the addition of glass nanoparticles to the polymer was showing a considerable effect on the pore morphology and the pore size of the final scaffolds.

\section{Isolation and in vitro expansion of MSCs}

Cells were obtained by bone marrow flashing and seeded at a high primary seeding density of $1 \times 10^{5} \mathrm{BM}$ mononuclear cells and day 2; by inverted phase-contrast microscope, elongated cells appeared and were selected by adherence to plastic, whereas floating cells are residual red blood cells and unattached mononuclear cells were maintained in expansion medium. On day 3, following removal of non-adherent hematopoietic stem cell populations by changing medium for the first time, colonies were formed of rounded, yellowish cells at the center and some spindle fibroblastoid adherent cells at the periphery (elongated with tapering ends) at day 3 and day 4 (Fig. 6a, b). BM-MSCs samples showed adherent spindle-shaped fibroblasts-like cells, rapidly dividing cells at days 5-7 following removal of non-adherent cells. Colonies of proliferating cells were seen radiating out of the explants after removing non-adherent cells at day 3 (Fig. 6c, d).

The plastic adherence and morphology of isolated cells were compatible with undifferentiated MSCs. The adherent spindle-shaped fibroblasts-like cells proliferated and expanded rapidly and reached confluence $(80-90 \%)$ by days 5-7 (Fig. 6e) at which time that the population was trypsinized and passaged. The confluence appeared as a fibroblastoid cell population around nodules in different fields of the flask and not the whole flask was a confluence. Nodular confluence was more important than flask confluence. The number of colonies varied from 3-7 per flask T25 $\mathrm{cm}^{2}$. After subculture in 24 well plates (Fig. 6f), the morphology of some cells within the population grown in osteogenic medium (non-toxic control material) approximately changed in the first $48-72 \mathrm{~h}$ following the addition of the osteogenic medium. Cuboidal cells protruding from the monolayer cell culture were observed. Rabbit BM-MSCs assumed a less elongated, polygonal, cuboidal appearance with central rounded nuclei or multipolar at day 3 (Fig. 7a-c), and the cells showed coalescing cellular aggregates arranged in swirling sheets and bundles with interconnected multilayer foci showing central matrix-like substance like nodules at day 7 (Fig. 7d-i). 

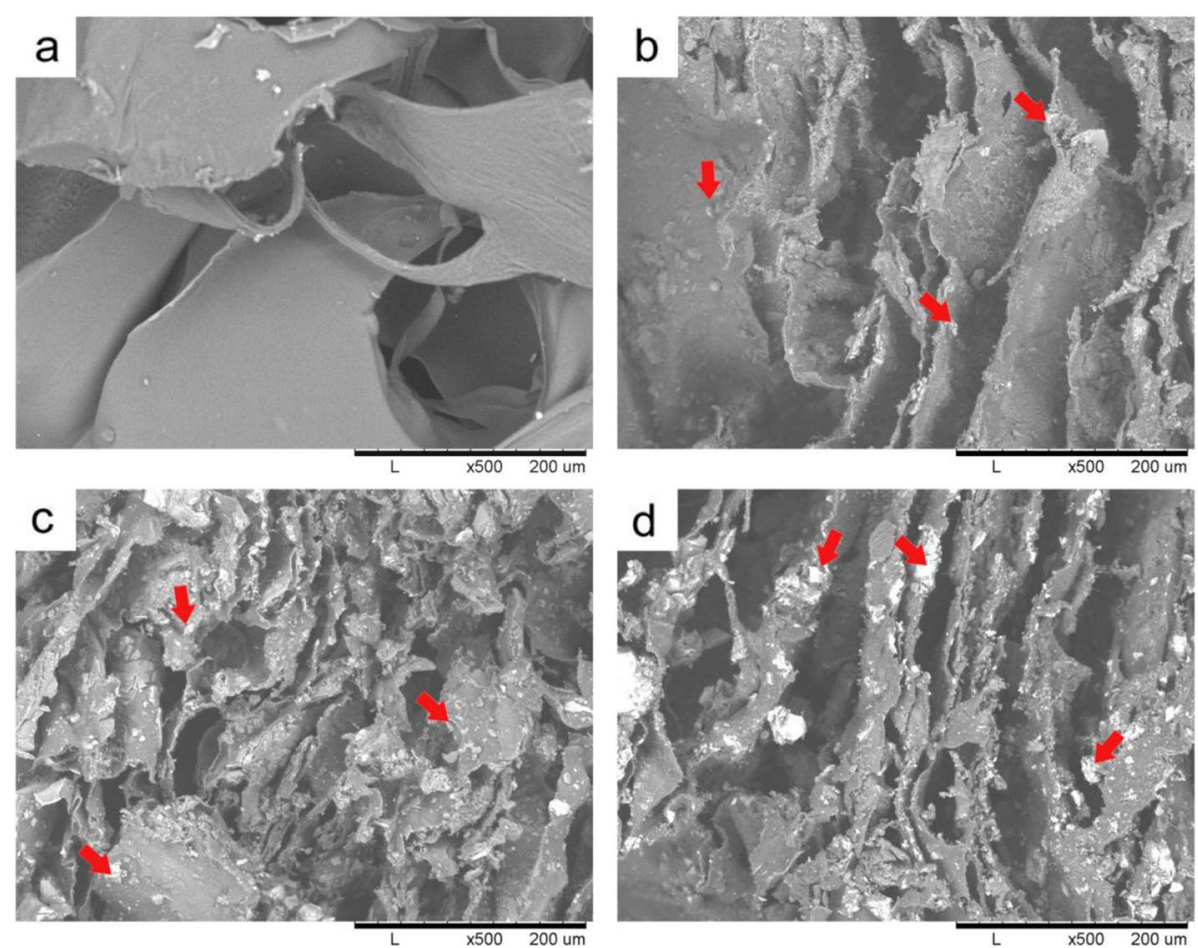

Fig. 5 SEM micrographs of the composite scaffolds, $\mathrm{CL} / \mathrm{CH}, \mathrm{CL} / \mathrm{CH} / \mathrm{CO}, \mathrm{CL} / \mathrm{CH} / \mathrm{C} 5$, and $\mathrm{CL} / \mathrm{CH} / \mathrm{C} 10$ samples (a, $\mathbf{b}$, c, and $\mathbf{d}$, respectively). Red arrows pointed to the glass particles distributed in the polymer matrix

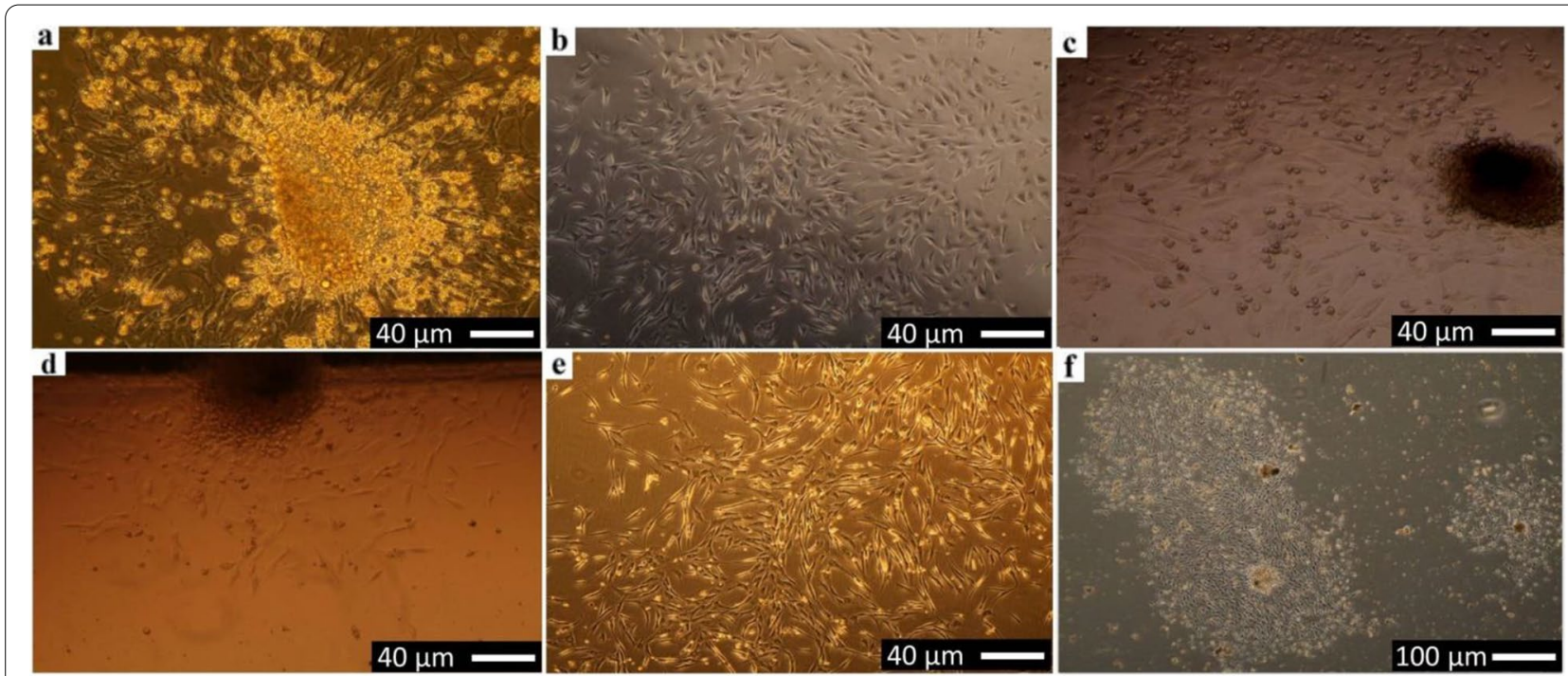

Fig. 6 Inverted phase-contrast micrographs show the morphology of primary cultured Rabbit BM-MSCs after removal of non-adherent cells in expansion medium (a-d) at days 3-4, (e) confluence (80-90\%) at days 5-7, (f) Nodular confluence (colonies varied from 3-7 per flask T25 $\mathrm{cm}^{2}$ )

\section{In vitro biocompatibility}

After the direct contact of the first passage of BM-MSCS in osteogenic medium with the four composite scaffolds for 1 day, the cells spread around the scaffold surfaces, the cell morphological changes, and increase in cell proliferation were observed obviously, especially around, in the vicinity and under the scaffold surfaces (Fig. 8 (a-c) $\mathrm{CL} / \mathrm{CH}$, (d-f) $\mathrm{CL} / \mathrm{CH} / \mathrm{CO}$, (g-i) $\mathrm{CL} / \mathrm{CH} / \mathrm{C} 5$, and (j-l) $\mathrm{C} /$ 


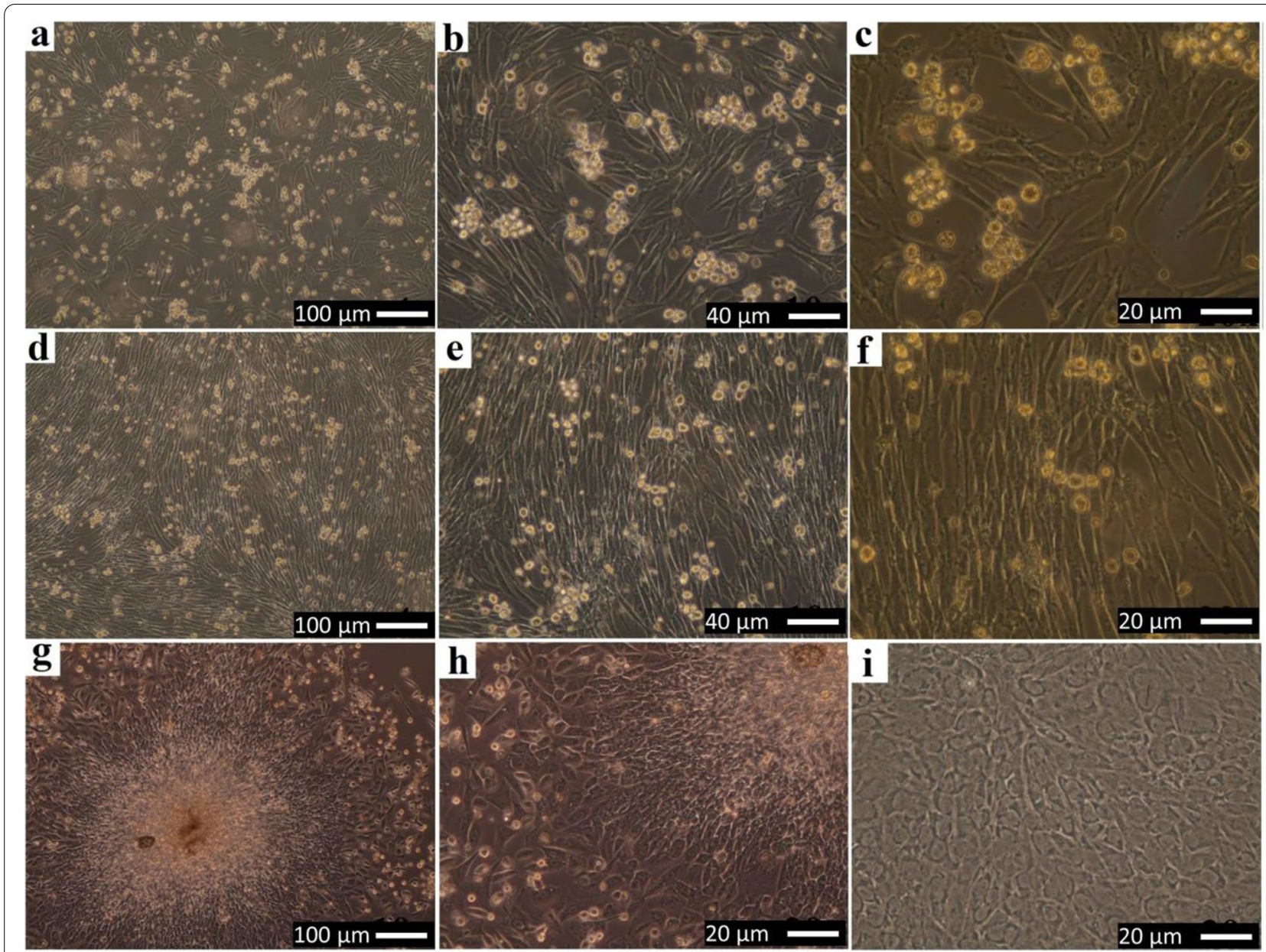

Fig. 7 Inverted phase-contrast micrographs show the morphology of sub-cultured Rabbit BM-MSCs in the osteogenic medium in polystyrene culture plate as a negative control material (a-c) at day 3 and $(\mathbf{d}-\mathbf{i})$ at day 7 , first passage through the first week of differentiation

$\mathrm{LCH} / \mathrm{C} 10)$. Initially, many cells incubated with all scaffolds for $24 \mathrm{~h}$ were rounded in their shapes, and then the cells became spindle in morphology and increased in density with time. All the composite scaffolds showed proliferation of cells $>50 \%$. Cells round in shape was in a state of synthesis of DNA (cell mitosis) which indicated that the cells had strong generation abilities. The number of spindles with fibroblast-like cells was increased more in density with the times especially around scaffold surfaces. From the Giemsa stain, it was clear that the cell proliferation was increased as the percentage of cerium in the glass incorporated into the scaffold also increased; all composite scaffolds showed proliferation of cells $>70 \%$. A large number of cells proliferate, migrate, and spread into nearly every corner of the porous material at day 3 (Fig. 9 (a) CL/CH, (e-f) CL/CH/CO, (i, j) CL/ $\mathrm{CH} / \mathrm{C} 5$, and $(\mathrm{m}, \mathrm{n}) \mathrm{CL} / \mathrm{CH} / \mathrm{C} 10)$ and on day 7 the population of the cells increased manifestly (Fig. 9 (b-d) CL/ $\mathrm{CH},(\mathrm{g}, \mathrm{h}) \mathrm{CL} / \mathrm{CH} / \mathrm{CO},(\mathrm{k}, \mathrm{l}) \mathrm{CL} / \mathrm{CH} / \mathrm{C} 5$, and $(\mathrm{o}, \mathrm{p}) \mathrm{CL} /$
$\mathrm{CH} / \mathrm{C} 10)$. The morphology of the cells/scaffolds at day 3 and day 7 was similar to the cells of the non-toxic negative control material. While the cells of negative control material were concentrated in the center of good culture and began to form a dense culture with foci; central matrix-like substance with different shapes defined as nodules (Fig. 9q-s), plain unseeded scaffolds were the same for all four composite scaffolds in culture medium (Fig. 9t). Another hand, PVC $20 \mathrm{mg} / \mathrm{ml}$ and PVC $100 \mathrm{mg} /$ $\mathrm{ml}$ with four composite scaffolds showed inhibition of cell proliferation more than $80 \%$ at $24 \mathrm{~h}$, cells death was observed (Fig. 10 (a) $\mathrm{CL} / \mathrm{CH}$, (b) $\mathrm{CL} / \mathrm{CH} / \mathrm{CO}$, (c) $\mathrm{CL} / \mathrm{CH} /$ $\mathrm{C} 5$, and (d) $\mathrm{CL} / \mathrm{CH} / \mathrm{C} 10$ ) and $100 \%$ at day 7 (no cells were observed in well culture plates and all wells became similar to plain unseeded scaffolds (Fig. 9t).

On the other side, cells proliferated well in the extracts of the four composites scaffolds (Fig. 11 (a, e) $\mathrm{CL} / \mathrm{CH},(\mathrm{b}, \mathrm{f}) \mathrm{CL} / \mathrm{CH} / \mathrm{CO}$, (c, g) $\mathrm{CL} / \mathrm{CH} / \mathrm{C} 5$, and (d, h) $\mathrm{CL} / \mathrm{CH} / \mathrm{C} 10)$ at magnification $10 \times, 20 \times$ respectively 


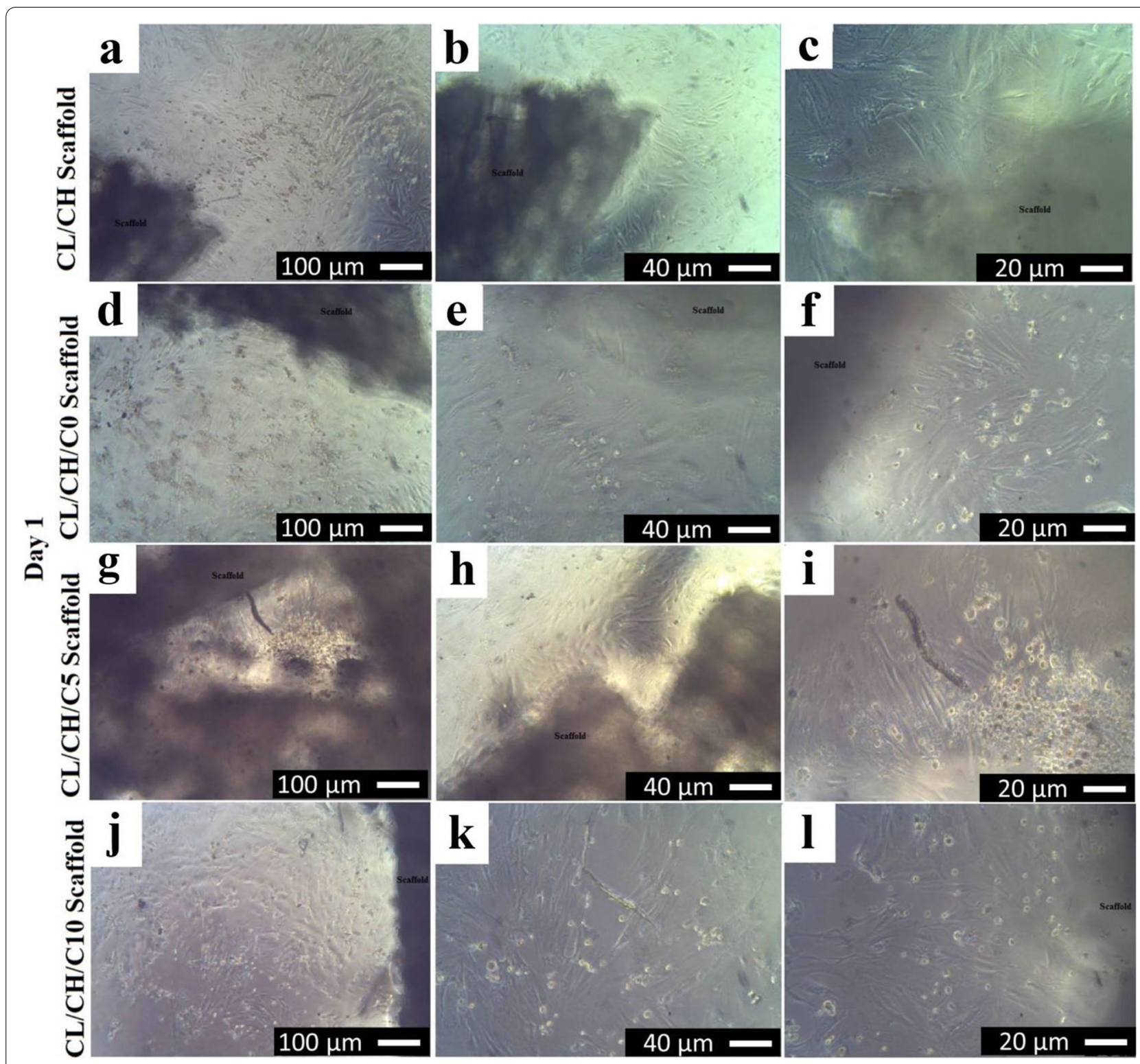

Fig. 8 Inverted phase-contrast micrographs show the morphology of sub-cultured Rabbit BM-MSCs in osteogenic medium (direct contact) toxicity test of the four composite scaffolds (a-c) $\mathrm{CL} / \mathrm{CH}$, (d-f) $\mathrm{CL} / \mathrm{CH} / \mathrm{CO}$, (g-i) $\mathrm{CL} / \mathrm{CH} / \mathrm{C} 5$, and $(\mathbf{j}-\mathbf{l}) \mathrm{CL} / \mathrm{CH} / \mathrm{C} 10)$ respectively

for all composite extracts. Although many rounded cells and few changes in cell morphology were observed after $24 \mathrm{~h}$ of seeding cells with scaffolds extracts in culture, with time, the cells settle and cell morphology became the same with four extracts at day 7 (Fig. 11i-l) and was similar to the cells of the non-toxic negative control material (Figs. $9 \mathrm{q}-\mathrm{s}$ and $11 \mathrm{~m}-\mathrm{o}$ ) at the same days. Positive control, PVC $20 \mathrm{mg} / \mathrm{ml}$ and $100 \mathrm{mg} / \mathrm{m}$, affected the viability and proliferation of cells with an inhibition value $>90 \%$ (toxic). Most cells died and detached from the bottom of the culture plate and then floated and removed after the first change of media (Fig. 11p). On day 7, no cells were observed in culture wells with (positive control material) in all extracts as showed before in field 2 (Fig. 10e). These results showed no toxicity presented in the extracts of scaffolds; the positive control material (PVC) was severely toxic and caused a marked detachment and death in cell culture.

\section{Cell proliferation assay}

MTT assay is an important method to evaluate the cytotoxicity of material where the scaffolds were slowly 


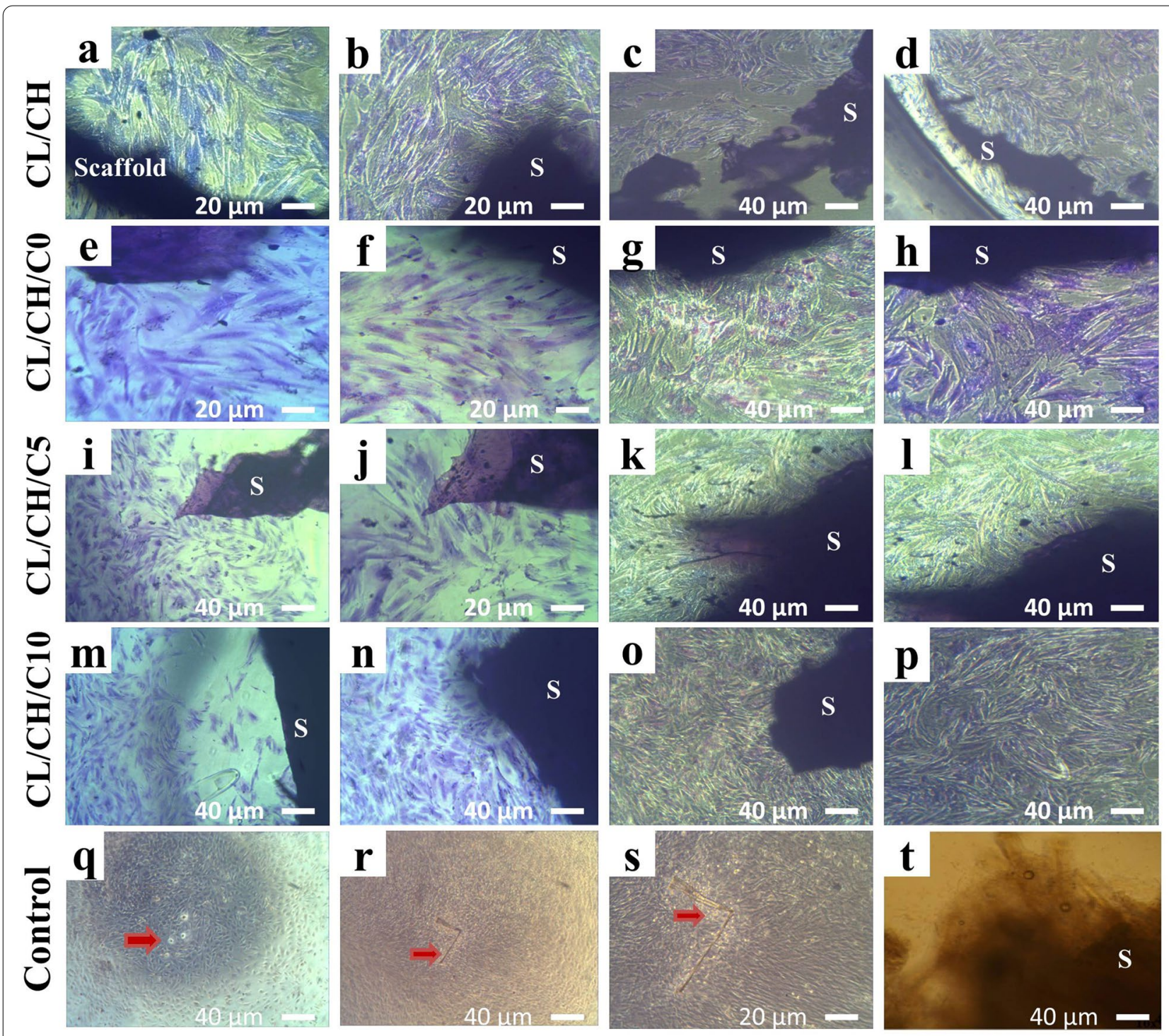

Fig. 9 Inverted phase-contrast micrographs show the morphology of sub-cultured Rabbit BM-MSCs in osteogenic medium (direct contact toxicity test) of the four composite scaffolds by Giemsa stain at day 3 (a) $\mathrm{CL} / \mathrm{CH}$, (e-f) $\mathrm{CL} / \mathrm{CH} / \mathrm{CO},(\mathbf{i}, \mathbf{j}) \mathrm{CL} / \mathrm{CH} / \mathrm{C} 5,(\mathbf{m}, \mathbf{n}) \mathrm{CL} / \mathrm{CH} / \mathrm{C} 10$ at day 7 (b-d) $\mathrm{CL} / \mathrm{CH}$, (g, h) $\mathrm{CL} / \mathrm{CH} / \mathrm{CO}$, (k, I) $\mathrm{CL} / \mathrm{CH} / \mathrm{C5}$, and $(\mathbf{o}, \mathbf{p}) \mathrm{C} / \mathrm{LCH} / \mathrm{C} 10)$ of incubation the cells with the four composite scaffolds compared to (q-s) cells of negative control material, (t) plain unseeded scaffolds

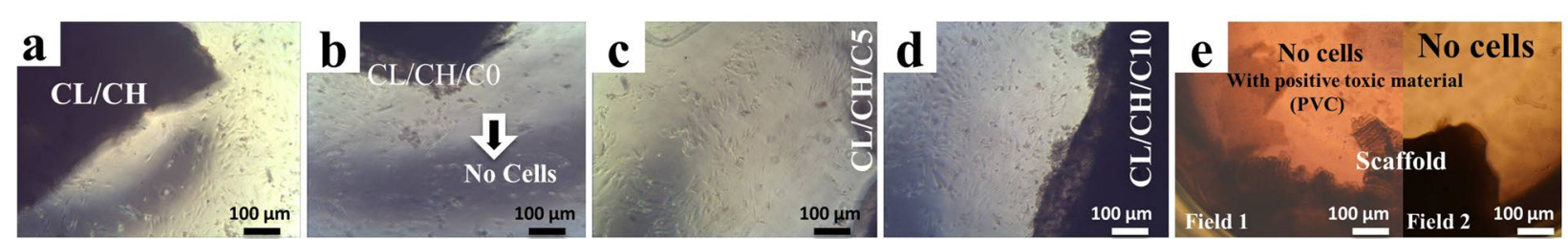

Fig. 10 Inverted phase-contrast micrographs show the morphology of the first passage Rabbit BM-MSCs (direct contact toxicity test) at day 3 (a) $\mathrm{CL} / \mathrm{CH}$, (b) $\mathrm{CL} / \mathrm{CH} / \mathrm{CO}$, (c) $\mathrm{CL} / \mathrm{CH} / \mathrm{C5}$, and (d) CL/CH/C10 scaffolds supplemented with PVC mg/ml, (e) at day 7 100\% (no cells were observed in well culture plates with PVC $\mathrm{mg} / \mathrm{ml}$ 


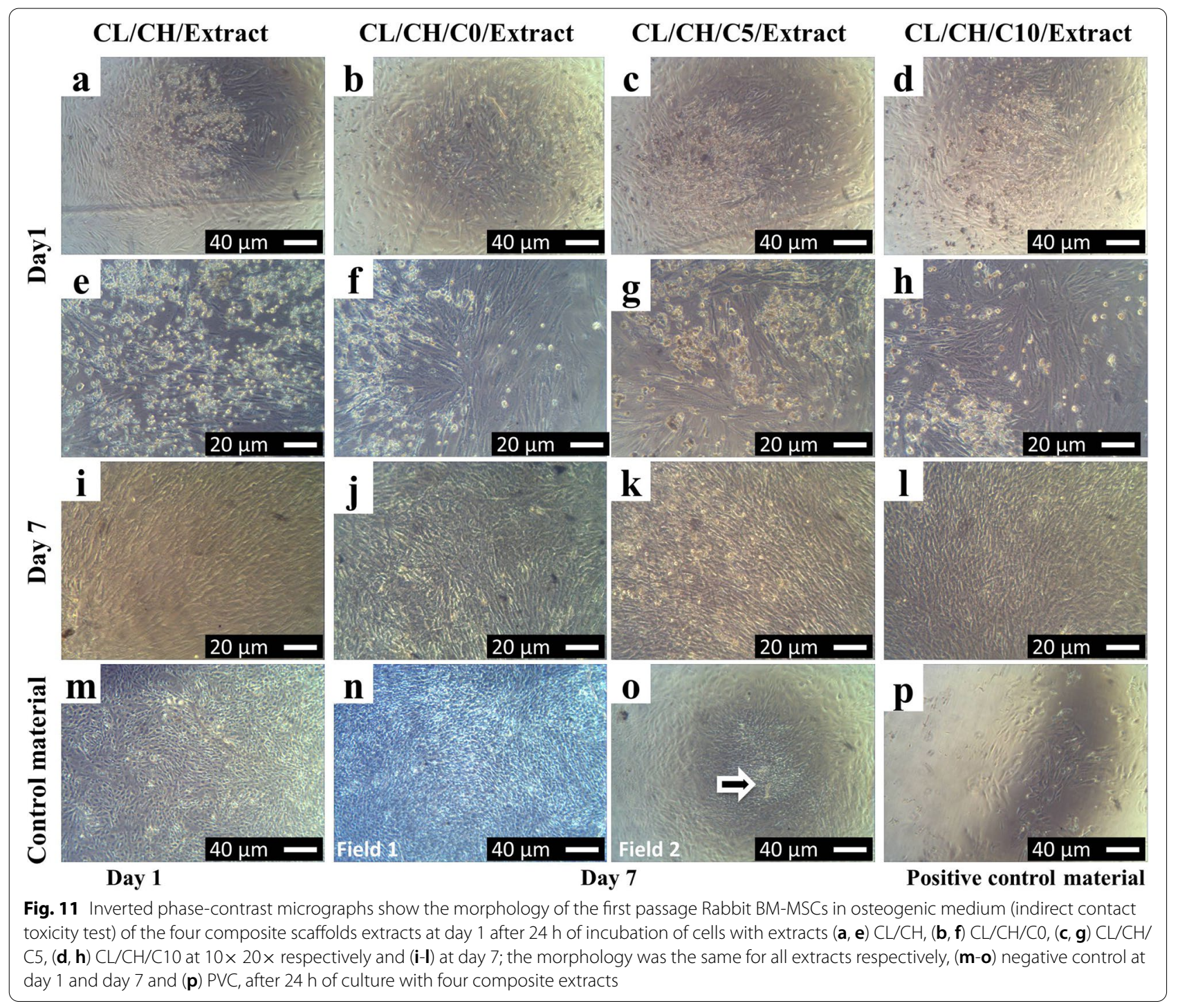

released components in the aqueous environment. Figure 12 shows the results of the MTT assay on day 1 and day 7 , which reflected the number of viable cells (cell proliferation) of the scaffolds. The tissue culture plastic polystyrene with culture media with cells was used as a non-toxic, negative control material and PVC $20 \mathrm{mg} / \mathrm{ml}$ and $100 \mathrm{mg} / \mathrm{ml}$ as positive control material. The statistical analysis of cell proliferation using one-way ANOVA test showed that the difference of cell proliferation at day 1 and day 7 of culturing was significant $(p<0.05)$ for $\mathrm{CL} / \mathrm{CH}, \mathrm{CL} / \mathrm{CH} / \mathrm{CO}$, and $\mathrm{CL} / \mathrm{CH} / \mathrm{C} 5$ scaffolds, while it was insignificant for $\mathrm{CL} / \mathrm{CH} / \mathrm{C} 10$. Moreover, the addition of nanobioactive glass particles (with/without Ce ion) to the scaffold polymer matrix increased the cell viability significantly $(p<0.05)$ either after 1 day or 7 days compared to the neat collagen/chitosan neat polymer scaffold. Meanwhile, at initial scaffolds cell culturing ( 1 day), the cell viability difference between $\mathrm{CL} / \mathrm{CH} / \mathrm{CO}$ and $\mathrm{CL} / \mathrm{CH} / \mathrm{C} 5$ was insignificant, while it became significant $(p<0.01)$ when the $\mathrm{CeO}_{2}$ percentage increased to $10 \%$ (sample $\mathrm{CL} / \mathrm{CH} / \mathrm{C} 10$ ). Hence, the effect of Ce content to increase the cell viability of the scaffolds containing bioactive glass particles was significant when $\mathrm{CeO}_{2}$ content was 10 mole\%, whereas the difference between these two scaffolds was insignificant after 7 days of cell culture. This can be explained by the consumption of $\mathrm{Ce}$ ions to interact with phosphate ions in the medium to form insoluble $\mathrm{CePO}_{4}$ crystals and thus decrease cell viability [41].

On the other hand, in the indirect contact test, few inhibitions of cell proliferation $<25 \%$ was detected for all prepared composite scaffold extracts by trypan blue and hemocytometer at day 7. This can be attributed to the dissolution of the scaffold materials 


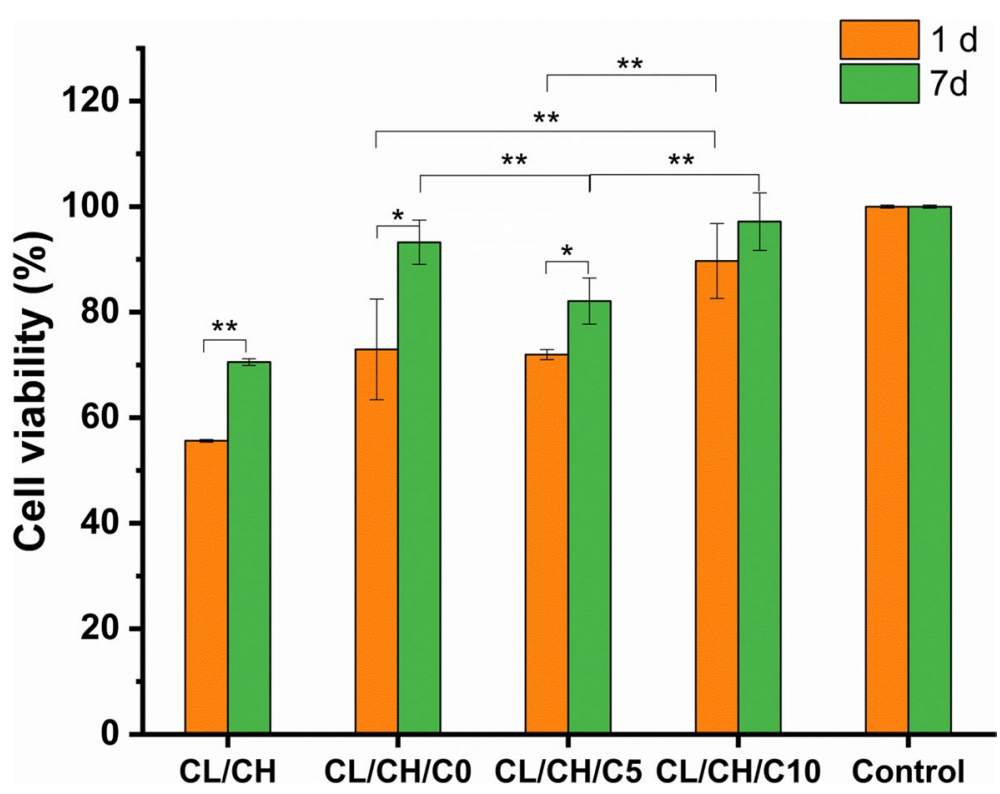

Fig. 12 MTTassay of $\mathrm{CL} / \mathrm{CH} /, \mathrm{CL} / \mathrm{CH} / \mathrm{CO}, \mathrm{CL} / \mathrm{CH} / \mathrm{C} 5$, and $\mathrm{CL} / \mathrm{CH} / \mathrm{C} 10$ composite scaffolds evaluated by proliferation of Rabbit BM-MSCs in osteogenic medium at day 1 and day 7 . All composite scaffolds showed proliferation inhibition $<25 \%$ at day 7 reference to final cell number of control negative material $\left(* P<0.05\right.$ and $\left.{ }^{* *} P<0.01\right)$

producing components causing a relatively small change in the cell environment which might change cell viability (Fig. 13).

\section{Discussion}

Recently, the cytotoxicity tests using cell lines are commonly used to estimate the biocompatibility of implanted biomaterials such as scaffolds, especially. Mouse fibroblast L929 and human osteoblast-like cell (HOB) are the most common cell line for bone regeneration purposes [71]. In this study, the cytotoxicity of the various composite scaffolds based on collagen and chitosan as natural polymer and nanobioactive glass doped with different ratios of $\mathrm{CeO}_{2}$ as a bioactive material was evaluated by using rabbit BM-MSCs directed to osteogenic lineage. The biocompatibility of the four composite scaffolds was evaluated in vitro by observing the behavior of the first passage of BMMSCs cultured in osteogenic medium close contact around or in the vicinity of the four composite scaffolds and other with its extracts using phase-contrast microscopy and MTT assay. These two combined analyses give an overview for direct correlation between toxicity, cell death, reduced cell proliferation, and altered morphology [71, 72].

In the other words, polymer-ceramic composites are favorite candidates when aiming to replace bone tissue. Most natural polymers like collagen and chitosan proved to possess good biocompatibility and osteogenesis.
Also, some ceramics, among which calcium phosphates (hydroxyapatite, the mineral phase of bone) and bioglass, have been shown positive effects on bone formation and cell fate in vivo and in vitro [73-80]. Nevertheless, there was no biocompatibility data of scaffold incorporated with NBG doped with different concentrations of $\mathrm{CeO}_{2}$.

The scaffold which caused cell death $>50 \%$ is considered toxic and unsafe to be used in biomedical applications [79]. Toxicity was tested by the death of $50 \%$ of cells (inhibition value $>50 /$ IC50). In our study, at $24 \mathrm{~h}$ after direct contact with scaffolds, little change in the cell morphology. Most of the cells became rounded, especially, cells in the vicinity of scaffold surfaces, after that, the cells settled and became spindle and elongated. Little decrease in cell number, no cell death was observed. The inhibitions of cell proliferation and change of cell morphology occurred directly with the scaffolds supplemented with PVC $20 \mathrm{mg} / \mathrm{ml}$ and $100 \mathrm{mg} / \mathrm{ml}$ were $>90 \%$. The inhibition was increased manifestly before reaching to day 7 until no attached cells were observed in the culture well (inhibition value 100\%). The scaffolds under investigation did not show a negative effect on cell morphology and activity, and so, they were nontoxic for cells. Generally, the scaffold is considered cytocompatible when it does not cause changes in cell morphology and activity [80].

Moreover, the effect of scaffolds extracts on the morphology of BMMSCs in the osteogenic medium was also evaluated using a phase-contrast microscope; an extremely useful technique for observing specimens that 


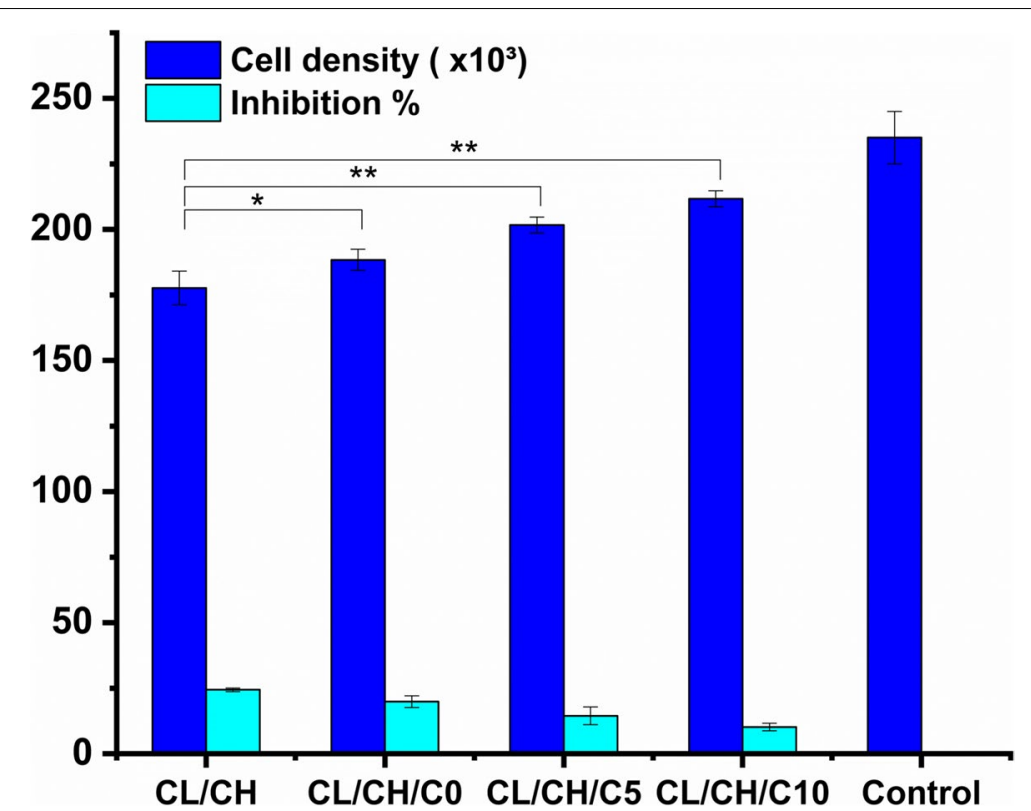

Fig. 13 Toxicity effect of $\mathrm{CL} / \mathrm{CH}, \mathrm{CL} / \mathrm{CH} / \mathrm{CO}, \mathrm{CL} / \mathrm{CH} / \mathrm{C} 5$, and $\mathrm{CL} / \mathrm{CH} / \mathrm{C} 10$ composite scaffold extracts evaluated by the proliferation of Rabbit BM-MSCs in the osteogenic medium after 7 days. All scaffolds extracts showed proliferation inhibition $<25 \%$ reference to final cell number of negative control material $\left({ }^{*} P<0.05\right.$ and ${ }^{* *} P<0.005$ )

were not been stained and were in their natural state. Obviously, the extracts of all composite scaffolds did not show a negative effect on the cell morphology, viability, and proliferation. Many rounded cells were observed with the four extracts were composed of scaffold materials resulting directly after $24 \mathrm{~h}$ of the culture of cells scaffolds extracts. Cells round in shape was in a state of synthesis of DNA (cell mitosis) [60], which indicated that the cells were having strong generation abilities as indicated on day 7 with quantities' test, MTT assay for the four composite scaffolds (direct contact test) and proliferation assay (indirect contact test) using trypan blue and hemocytometer counting; rapid count generates accurate cell counts and viability results in seconds for the four scaffolds extracts. Assays revealed that none of the composite scaffolds and their extracts were negatively affected on the viability of the cells (inhibition value $<25 \%$ ), and few deaths of the cells were observed. One possible explanation was weakness in a cellular environment (quality cells, culture media, and condition of incubation) in addition to the dissolution of scaffold materials result in cellular environment changes that reduce cell viability, all this must be taken into consideration that may affect the interpretation of scaffold toxicity if the calculation is based only in final cell count. Therefore, in this study, an inhibition percentage was determined by reference to the final cell number in control groups and compared to the four composite scaffolds and their extracts $\mathrm{CL} / \mathrm{CH}, \mathrm{CL} / \mathrm{CH} / \mathrm{CO}, \mathrm{CL} / \mathrm{CH} / \mathrm{C} 5$, and $\mathrm{CL} / \mathrm{CH} /$
C10 which supplemented with PVC $20 \mathrm{mg} / \mathrm{ml}$ and 100 $\mathrm{mg} / \mathrm{ml}$ and PVC showed inhibition of cell proliferation more than $90 \%$. This result was consistent with the result of the study, which reported previously [60], in which the authors stated that there was no cellular toxicity, impairment of cell adhesion to the plastic substrate (negative control), and decrease in cell viability found in the positive control, PVC was responsible for the cytotoxicity [60].

Testing of cell inhibition for composite scaffolds and its extracts showed that the inhibition was ordered from high to low as $\mathrm{CL} / \mathrm{CH}>\mathrm{CL} / \mathrm{CH} / \mathrm{CO}>\mathrm{CL} / \mathrm{CH} /$ $\mathrm{C} 5>\mathrm{CL} / \mathrm{CH} / \mathrm{C} 10$. Accordingly, osteoblasts proliferation was higher by incorporation of bioactive glass nanoparticles with polymer than the neat polymer, which indicated that the bioactive glass had stimulating effects to promote cell proliferation rate. This result was confirmed by several previous studies that used mainly natural polymers collagen and chitosan for bone regeneration and their conclusion for bone regeneration purposes was that collagen and chitosan polymers need bioactive material which can mimic the natural function of bone and improve unfavorable properties of natural polymer collagen and chitosan such as loss of osteoinductivity, low osteogenesis of collagen [9] and loss of osteoconductivity of chitosan which considers a very important property for bone healing in vivo after that [13]. Also, the addition of glass nanoparticles to the polymer was showed a considerable effect 
on the pore morphology and the pore size of the final scaffolds that characterized collagen/chitosan scaffold (sample $\mathrm{CL} / \mathrm{CH}$ ) with circular and relatively large pore size $(50-300 \mu \mathrm{m})$, while the scaffolds contained bioactive glass fillers were characterized by elongated and a relatively small pore size. The biocompatibility of the scaffold was increased as the percentage of $\mathrm{CeO}_{2}$ bioactive glass nanoparticles increased, specifically, at 10 mole\% of $\mathrm{CeO}_{2}$. The result is in agreement with previous observations on other Ce-containing biocomposite systems, wherein the bone-cell responses of the scaffold were enhanced by incorporating a suitable amount of Ce ions [81]. Seal and co-workers reported that Ce ions could increase the production of Collagen by human mesenchymal stem cells (HMSCs) cultured on porous bioactive glass scaffolds [81]. Porous bioactive glass scaffolds, which have been used clinically, can bind to the bone and act as a temporary guide and stimulus for bone growth in three dimensions.

Bone marrow-derived HMSCs line is a crucial cell type for bone regeneration in vivo because they differentiate into osteoprogenitor cells. It was reported that HMSCs are sensitive to toxic compounds derived from molecular oxygen. Ce ions can increase the proliferation of HMSCs by neutralizing oxidative stress [81]. Thus, embedding these ions into porous three-dimensional bioactive glass foam scaffolds could enhance osteoblastic differentiation of HMSCs and collagen formation. So, high Ce ion concentrations in samples exhibit cell viability higher than low concentration. These findings can be confirmed by the result of FTIR of the four composite scaffolds which indicated that the addition of $\mathrm{CeO}_{2}$ at expense of $\mathrm{CaO}$ was disrupted the silicate glass network and increased NBOs throughout the network [68]. The presence of a large number of NBOs increases the reactivity of the glass surface in the biological fluid and hence stimulates apatite formation with the surrounding tissues [69].

Hence, the biological effect of $\mathrm{Ce}$ ions in vitro and in vivo analyses contributes to its antioxidant activity. The effect of composite scaffolds containing $\mathrm{CeO}_{2}$ on the biological response might be ascribed either to the chemical nature of Ce ion or from the physical and morphological changes in roughness and stiffness brought to the composite scaffolds.

In the present study, with time through 1 week, the cell viability tests of the Ce-doped nanobioactive glass composite scaffolds and its extracts showed little inhibitions. This confirmed on high biocompatibility and also the early bioactivity of the composite scaffolds and their extracts was characterized by changing the BMMSCs morphology to osteoblast-like cells in a culture plate accompanied by the appearance of some early markers of osteoblast cells such as bone nodule formation while other markers are not detected in the present study. The bioactivity of these scaffolds and their extracts were discussed in detail in a complementary accepted study; the main target of it was the study of the bioactivity effect of these composite scaffolds toward osteogenic differentiation of normal rabbit's osteoblast cells derived from bone marrow mesenchymal stem cells and studying also anticancer activity.

Accordingly, these findings showed that incorporation of Ce-doped nanobioactive glass in collagen/ chitosan polymeric scaffolds increased proliferation of BMMSCs cultured under osteogenic condition for osteogenic lineage, hence, demonstrated a great potential for basic research and for future bone tissue engineering applications, especially when $\mathrm{CeO}_{2}$ was reported to exhibit positive effects (such as scavenging reactive oxygen species, ROS in other studies) [82] and so, the composite scaffolds were regarded as promising bioactive materials for biomedical applications.

\section{Conclusions}

Nanobioactive glass supported the attachment and proliferation of BM-MSCs, and provided an appropriate environment for cell proliferation. The incorporation of $\mathrm{CeO}_{2}$ in the glass composition which used as a bioactive filler of collagen/chitosan scaffolds increased cell viability and proliferation. The composite scaffold with the highest content of $\mathrm{CeO}_{2}$ content $(\mathrm{CL} / \mathrm{CH} / \mathrm{C} 10)$ showed the least toxic effect to BM-MSCs directed to osteogenic lineage. Ce ions were enhanced the early osteogenic proliferation that can be used for studying the bone mineralization process after that. Thus, these findings showed that the prepared hybrid Ce-doped glass/collagen/chitosan bioactive scaffolds were biocompatible and hold great potential for basic research and bone tissue engineering applications.

\section{Supplementary Information}

The online version contains supplementary material available at https://doi. org/10.1186/s43141-022-00302-x.

Additional file 1.

\section{Acknowledgements}

The authors would like to thank the National Research Centre (Biomaterials Group), National Cancer Institute (Cairo University), and Faculty of Science (Beni-Suef University), Egypt, for a possibility to use their facilities. 


\section{Authors' contributions}

$\mathrm{HFH}$ and MMF wrote the manuscript. MMFEL-D, MAG, and BMM conceived the idea. MMF edited the manuscript. All authors have read and approved the manuscript.

\section{Funding}

No funding was applied for this article.

\section{Availability of data and materials}

Not applicable for this articles.

\section{Declarations}

\section{Ethics approval and consent to participate}

The rabbits were scarified without complication to animals by cervical dislocation in the animal house lab using the guidelines approved by the Medical Research Ethics Committee on the use of Animal Subjects at National Cancer Institute.

\section{Consent for publication}

Not applicable for this articles.

\section{Competing interests}

The authors declare that they have no competing interests.

\section{Author details}

${ }^{1}$ The Healthy Chemistry Department, Center Health Laboratory, Ministry of Health, Cairo, Egypt. ${ }^{2}$ Glass Research Department, National Research Centre, 33 El Bohouth Str., Dokki, Giza 12622, Egypt. ${ }^{3}$ Department Pathology, Tissue Culture and Cytogenesis Unit, National Cancer Institute, Cairo University, Cairo, Egypt. ${ }^{4}$ Departmentof Chemistry, Faculty of Science, Beni-Suef University, Beni-Suef, Egypt.

Received: 11 August 2021 Accepted: 15 January 2022

Published online: 21 February 2022

\section{References}

1. Ahlmann E, Patzakis M, Roidis N, Shepherd L, Holtom P (2002) Comparison of anterior and posterior iliac crest bone grafts in terms of harvestsite morbidity and functional outcomes. JBJS 84(5):716-720

2. Younger EM, Chapman MW (1989) Morbidity at bone graft donor sites. J Orthop Trauma 3(3):192-195

3. St John TA, Vaccaro AR, Sah AP, Schaefer M, Berta SC, Albert T, Hilibrand A (2003) Physical and monetary costs associated with autogenous bone graft harvesting. Am J Orthop 32(1):18-23

4. Campana V, Milano G, Pagano E, Barba M, Cicione C, Salonna G, Lattanzi W, Logroscino G (2014) Bone substitutes in orthopaedic surgery: from basic science to clinical practice. J Mater Sci Mater Med 25(10):2445-2461

5. Wang W, Yeung KW (2017) Bone grafts and biomaterials substitutes for bone defect repair: a review. Bioactive Mater 2(4):224-247

6. Lehmann G, Palmero P, Cacciotti I, Pecci R, Campagnolo L, Bedini R, Siracusa G, Bianco A, Camaioni A, Montanaro L (2010) Design, production and biocompatibility of nanostructured porous HAp and Si-HAp ceramics as three-dimensional scaffolds for stem cell culture and differentiation. Ceramics Silikaty 54(2):90-96

7. Gordon T, Schloesser L, Humphries D, Spector M (2004) Effects of the degradation rate of collagen matrices on articular chondrocyte proliferation and biosynthesis in vitro. Tissue Eng 10(7-8):1287-1295

8. Ignatius A, Blessing H, Liedert A, Schmidt C, Neidlinger-Wilke C, Kaspar D, Friemert B, Claes $L$ (2005) Tissue engineering of bone: effects of mechanical strain on osteoblastic cells in type I collagen matrices. Biomaterials 26(3):311-318

9. Zhang D, Wu X, Chen J, Lin K (2018) The development of collagen based composite scaffolds for bone regeneration. Bioactive Mater $3(1): 129-138$

10. Rinaudo M (2006) Chitin and chitosan: properties and applications. Prog Polym Sci 31(7):603-632
11. Lahiji A, Sohrabi A, Hungerford DS, Frondoza CG (2000) Chitosan supports the expression of extracellular matrix proteins in human osteoblasts and chondrocytes. J Biomed Mater Res 51(4):586-595

12. Rodríguez-Vázquez M, Vega-Ruiz B, Ramos-Zúñiga $R$, Saldaña-Koppel DA, Quiñones-Olvera LF (2015) Chitosan and its potential use as a scaffold for tissue engineering in regenerative medicine. Biomed Res Int 2015:821279

13. Amini AR, Laurencin CT, Nukavarapu SP (2012) Bone tissue engineering: recent advances and challenges. Crit Rev Biomed Eng 40(5):363

14. Liu C, Xia Z, Czernuszka J (2007) Design and development of threedimensional scaffolds for tissue engineering. Chem Eng Res Des 85(7):1051-1064

15. Ma L, Gao C, Mao Z, Zhou J, Shen J, Hu X, Han C (2003) Collagen/chitosan porous scaffolds with improved biostability for skin tissue engineering. Biomaterials 24(26):4833-4841

16. Tangsadthakun C, Kanokpanont S, Sanchavanakit N, Banaprasert T, Damrongsakkul S (2017) Properties of collagen/chitosan scaffolds for skin tissue engineering. J Met Mater Minerals 16(1):37-44

17. Mahmoud AA, Salama AH (2016) Norfloxacin-loaded collagen/chitosan scaffolds for skin reconstruction: preparation, evaluation and in-vivo wound healing assessment. Eur J Pharm Sci 83:155-165

18. Zhu C, Fan D, Duan Z, Xue W, Shang L, Chen F, Luo Y (2009) Initial investigation of novel human-like collagen/chitosan scaffold for vascular tissue engineering. J Biomed Mater Res A 89(3):829-840

19. Zhu C, Fan D, Ma X, Xue W, Yu Y, Luo Y, Liu B, Chen L (2009) Effects of chitosan on properties of novel human-like collagen/chitosan hybrid vascular scaffold. J Bioact Compat Polym 24(6):560-576

20. Huang C, Chen R, Ke Q, Morsi Y, Zhang K, Mo X (2011) Electrospun collagen-chitosan-TPU nanofibrous scaffolds for tissue engineered tubular grafts. Colloids Surf B: Biointerfaces 82(2):307-315

21. Venkatesan J, Lowe B, Kim S-K (2015) Bone tissue engineering using functional marine biomaterials. In: Functional Marine Biomaterials. Elsevier, pp 53-61

22. Wang Y, Zhang L, Hu M, Liu H, Wen W, Xiao H, Niu Y (2008) Synthesis and characterization of collagen-chitosan-hydroxyapatite artificial bone matrix. J Biomed Mater Res A 86(1):244-252

23. Hench LL, Splinter RJ, Allen W, Greenlee T (1971) Bonding mechanisms at the interface of ceramic prosthetic materials. J Biomed Mater Res 5(6):117-141

24. Hench LL (1998) Bioactive materials: the potential for tissue regeneration J Biomed Mater Res 41(4):511-518

25. Rahaman MN, Day DE, Bal BS, Fu O Jung SB, Bonewald LF, Tomsia AP (2011) Bioactive glass in tissue engineering. Acta Biomater 7(6):2355-2373

26. Andrade ÂL, Valério P, Goes AM, de Fátima LM, Domingues RZ (2006) Influence of morphology on in vitro compatibility of bioactive glasses. J Non-Cryst Solids 352(32-35):3508-3511

27. Hench L, Wheeler D, Greenspan D (1998) Molecular control of bioactivity in sol-gel glasses. J Sol-Gel Sci Technol 13:245-250

28. Carvajal S, Perramón M, Casals G, Oró D, Ribera J, Morales-Ruiz M, Casals E, Casado P, Melgar-Lesmes P, Fernández-Varo G (2019) Cerium oxide nanoparticles protect against oxidant injury and interfere with oxidative mediated kinase signaling in human-derived hepatocytes. Int J Mol Sci 20(23):5959

29. Korsvik C, Patil S, Seal S, SelfWT (2007) Superoxide dismutase mimetic properties exhibited by vacancy engineered ceria nanoparticles. Chem Commun: 10, 1056-1058

30. Pirmohamed T, Dowding JM, Singh S, Wasserman B, Heckert E, Karakoti AS, King JE, Seal S, Self WT (2010) Nanoceria exhibit redox state-dependent catalase mimetic activity. Chem Commun 46(16):2736-2738

31. Du J, Kokou L, Rygel JL, Chen Y, Pantano CG, Woodman R, Belcher J (2011) Structure of cerium phosphate glasses: molecular dynamics simulation. J Am Ceram Soc 94(8):2393-2401

32. Leonelli C, Lusvardi G, Malavasi G, Menabue L, Tonelli M (2003) Synthesis and characterization of cerium-doped glasses and in vitro evaluation of bioactivity. J Non-Cryst Solids 316(2):198-216

33. Goh Y-F, Alshemary AZ, Akram M, Kadir MRA, Hussain R (2014) In-vitro characterization of antibacterial bioactive glass containing ceria. Ceram Int 40(1):729-737

34. Shruti S, Salinas AJ, Malavasi G, Lusvardi G, Menabue L, Ferrara C, Mustarelli P. Vallet-Regì M (2012) Structural and in vitro study of cerium, 
gallium and zinc containing sol-gel bioactive glasses. J Mater Chem 22(27):13698-13706

35. Zhang J, Liu C, Li Y, Sun J, Wang P, Di K, Zhao Y (2010) Effect of cerium ion on the proliferation, differentiation and mineralization function of primary mouse osteoblasts in vitro. J Rare Earths 28(1):138-142

36. Deliormanlı AM (2015) Synthesis and characterization of cerium- and gallium-containing borate bioactive glass scaffolds for bone tissue engineering. J Mater Sci Mater Med 26(2):67

37. Gupta B, Papke JB, Mohammadkhah A, Day DE, Harkins AB (2016) Effects of chemically doped bioactive borate glass on neuron regrowth and regeneration. Ann Biomed Eng 44(12):3468-3477

38. Nicolini V, Malavasi G, Menabue L, Lusvardi G, Benedetti F, Valeri S, Luches P (2017) Cerium-doped bioactive 4555 glasses: spectroscopic, redox, bioactivity and biocatalytic properties. J Mater Sci 52(15):8845-8857

39. Nicolini V, Varini E, Malavasi G, Menabue L, Menziani MC, Lusvardi G, Pedone A, Benedetti F, Luches P (2016) The effect of composition on structural, thermal, redox and bioactive properties of Ce-containing glasses. Mater Des 97:73-85

40. Placek L, Keenan T, Coughlan A, Wren A (2018) Investigating the effect of glass ion release on the cytocompatibility, antibacterial efficacy and antioxidant activity of $\mathrm{Y} 2 \mathrm{O} 3 / \mathrm{CeO} 2$-doped $\mathrm{SiO} 2-\mathrm{SrO}-\mathrm{Na} 2 \mathrm{O}$ glasses. Biomed Glasses 4(1):32-44

41. Farag MM, Al-Rashidy ZM, Ahmed MM (2019) In vitro drug release behavior of Ce-doped nano-bioactive glass carriers under oxidative stress. J Mater Sci Mater Med 30(2):18

42. Zou X, Li H, Chen L, Baatrup A, Bünger C, Lind M (2004) Stimulation of porcine bone marrow stromal cells by hyaluronan, dexamethasone and rhBMP-2. Biomaterials 25(23):5375-5385

43. Chen CT, Shih YRV, Kuo TK, Lee OK, Wei YH (2008) Coordinated changes of mitochondrial biogenesis and antioxidant enzymes during osteogenic differentiation of human mesenchymal stem cells. Stem Cells 26(4):960-968

44. Ko E, Lee KY, Hwang DS (2012) Human umbilical cord blood-derived mesenchymal stem cells undergo cellular senescence in response to oxidative stress. Stem Cells Dev 21(11):1877-1886

45. Alves H, Munoz-Najar U, De Wit J, Renard AJ, Hoeijmakers JH, Sedivy JM, Van Blitterswijk C, De Boer J (2010) A link between the accumulation of DNA damage and loss of multi-potency of human mesenchymal stromal cells. J Cell Mol Med 14(12):2729-2738

46. Choo KB, Tai L, Hymavathee KS, Wong CY, Nguyen PNN, Huang C-J, Cheong SK, Kamarul T (2014) Oxidative stress-induced premature senescence in Wharton's jelly-derived mesenchymal stem cells. Int J Med Sci 11(11):1201

47. Tsutsumi S, Shimazu A, Miyazaki K, Pan H, Koike C, Yoshida E, Takagishi K, Kato Y (2001) Retention of multilineage differentiation potential of mesenchymal cells during proliferation in response to FGF. Biochem Biophys Res Commun 288(2):413-419

48. Shruti S, Salinas AJ, Lusvardi G, Malavasi G, Menabue L, Vallet-Regi M (2013) Mesoporous bioactive scaffolds prepared with cerium-, galliumand zinc-containing glasses. Acta Biomater 9(1):4836-4844

49. Deliormanlı AM (2015) Synthesis and characterization of cerium-and gallium-containing borate bioactive glass scaffolds for bone tissue engineering. J Mater Sci Mater Med 26(2):67

50. Deliormanlı AM (2016) Electrospun cerium and gallium-containing silicate based 13-93 bioactive glass fibers for biomedical applications. Ceram Int 42(1):897-906

51. Ibrahim AM, Al-Rashidy ZM, Ghany NAA, Ahmed HY, Omar AE, Farag MM (2021) Bioactive and antibacterial metal implant composite coating based on Ce-doped nanobioactive glass and chitosan by electrophoretic deposition method. J Mater Res: 36, 1899-1913

52. Müller U (2008) In vitro biocompatibility testing of biomaterials and medical devices. Med Device Technol 19(2):30, 32-30, 34

53. Vert M, Doi Y, Hellwich K-H, Hess M, Hodge P, Kubisa P, Rinaudo M, Schué F (2012) Terminology for biorelated polymers and applications (IUPAC Recommendations 2012). Pure Appl Chem 84(2):377-410

54. Xia W, Chang J (2007) Preparation and characterization of nano-bioactive-glasses (NBG) by a quick alkali-mediated sol-gel method. Mater Lett 61(14):3251-3253

55. El-Kady AM, Saad EA, El-Hady BMA, Farag MM (2010) Synthesis of silicate glass/poly(l-lactide) composite scaffolds by freeze-extraction technique: characterization and in vitro bioactivity evaluation. Ceram Int 36(3):995-1009

56. Jiang $Y$, Jahagirdar BN, Reinhardt RL, Schwartz RE, Keene CD, Ortiz-Gonzalez XR, Reyes M, LenvikT, Lund T, Blackstad M (2002) Pluripotency of mesenchymal stem cells derived from adult marrow. Nature 418(6893):41-49

57. Hinds KA, Hill JM, Shapiro EM, Laukkanen MO, Silva AC, Combs CA, Varney TR, Balaban RS, Koretsky AP, Dunbar CE (2003) Highly efficient endosomal labeling of progenitor and stem cells with large magnetic particles allows magnetic resonance imaging of single cells. Blood 102(3):867-872

58. Friedenstein A, Chailakhyan R, Gerasimov U (1987) Bone marrow osteogenic stem cells: in vitro cultivation and transplantation in diffusion chambers. Cell Prolif 20(3):263-272

59. Jaiswal N, Haynesworth SE, Caplan Al, Bruder SP (1997) Osteogenic differentiation of purified, culture-expanded human mesenchymal stem cells in vitro. J Cell Biochem 64(2):295-312

60. Zhou Z, Chen L (2008) Morphology expression and proliferation of human osteoblasts on bioactive glass scaffolds. Mater Sci Poland 26(3):506-516

61. Xiong G, Luo H, Gu F, Zhang J, Hu D, Wan Y (2013) A novel in vitro threedimensional macroporous scaffolds from bacterial cellulose for culture of breast cancer cells. J Biomater Nanobiotechnol 4(04):316

62. Kosaka T, Fukaya K-i, Tsuboi S, Pu H, Ohno T, Tsuji T, Namba M (1996) Comparison of various methods of assaying the cytotoxic effects of ethanol on human hepatoblastomaells (HUH-6 Line). Acta Med Okayama 50(3):151-156

63. Strober W (2015) Trypan blue exclusion test of cell viability. Curr Protoc Immunol 111(1):A3. B. 1-A3. B. 3

64. Ashuri M, Moztarzadeh F, Nezafati N, Hamedani AA, Tahriri M (2012) Development of a composite based on hydroxyapatite and magnesium and zinc-containing sol-gel-derived bioactive glass for bone substitute applications. Mater Sci Eng C 32(8):2330-2339

65. Saboori A, Rabiee M, Moztarzadeh F, Sheikhi M, Tahriri M, Karimi M (2009) Synthesis, characterization and in vitro bioactivity of sol-gel-derived SiO2-CaO-P2O5-MgO bioglass. Mater Sci Eng C 29(1):335-340

66. Zhang E, Zou C, Yu G (2009) Surface microstructure and cell biocompatibility of silicon-substituted hydroxyapatite coating on titanium substrate prepared by a biomimetic process. Mater Sci Eng C 29(1):298-305

67. Serra J, Gonzalez P, Liste S, Chiussi S, Leon B, Pérez-Amor M, Ylänen H, Hupa M (2002) Influence of the non-bridging oxygen groups on the bioactivity of silicate glasses. J Mater Sci Mater Med 13(12):1221-1225

68. Deliormanlı AM, Yıldırım M (2016) Sol-gel synthesis of 13-93 bioactive glass powders containing therapeutic agents. J Aust Ceramic Soc Vol 52(2):9-19

69. Oliveira J, Correia R, Fernandes M (2002) Effects of Si speciation on the in vitro bioactivity of glasses. Biomaterials 23(2):371-379

70. Hesaraki S, Gholami M, Vazehrad S, Shahrabi S (2010) The effect of Sr concentration on bioactivity and biocompatibility of sol-gel derived glasses based on CaO-SrO-SiO 2-P 205 quaternary system. Mater Sci Eng C 30(3):383-390

71. Idris SB, Dånmark S, Finne-Wistrand A, Arvidson K, Albertsson A-C, Bolstad Al, Mustafa K (2010) Biocompatibility of polyester scaffolds with fibroblasts and osteoblast-like cells for bone tissue engineering. J Bioact Compat Polym 25(6):567-583

72. Silva GA, Marques A, Gomes ME, Coutinho O, Reis RL (2004) Cytotoxicity screening of biodegradable polymeric systems. In: Biodegradable Systems in Tissue Engineering and Regenerative Medicine. CRC Press, Boca Raton, pp 339-349

73. Rothamel D, Schwarz F, Sculean A, Herten M, Scherbaum W, Becker $J$ (2004) Biocompatibility of various Collagen membranes in cultures of human PDL fibroblasts and human osteoblast-like cells. Clin Oral Implants Res 15(4):443-449

74. Cho JH, Kim S-H, Park KD, Jung MC, Yang WI, Han SW, Noh JY, Lee JW (2004) Chondrogenic differentiation of human mesenchymal stem cells using a thermosensitive poly ( $\mathrm{N}$-isopropylacrylamide) and water-soluble Chitosan copolymer. Biomaterials 25(26):5743-5751

75. Dang JM, Sun DD, Shin-Ya Y, Sieber AN, Kostuik JP, Leong KW (2006) Temperature-responsive hydroxybutyl chitosan for the culture of mesenchymal stem cells and intervertebral disk cells. Biomaterials 27(3):406-418

76. Hoppe A, Boccardi E, Ciraldo F, Boccaccini A, Hill R (2017) Bioactive glassceramics. Comprehensive Biomaterials II, 1:235-43 
77. Chen Q, Efthymiou A, Salih V, Boccaccini AR (2008) Bioglass ${ }^{\circledR}$-derived glass-ceramic scaffolds: study of cell proliferation and scaffold degradation in vitro. J Biomed Mater Res A 84(4):1049-1060

78. Muzzarelli RA (2009) Chitins and chitosans for the repair of wounded skin, nerve, cartilage and bone. Carbohydr Polym 76(2):167-182

79. Fotakis G, Timbrell JA (2006) In vitro cytotoxicity assays: comparison of LDH, neutral red, MTT and protein assay in hepatoma cell lines following exposure to cadmium chloride. Toxicol Lett 160(2):171-177

80. Kamal AF, Iskandriati D, Dilogo IH, Siregar NC, Hutagalung EU, Susworo R, Yusuf AA, Bachtiar A (2013) Biocompatibility of various hydoxyapatite scaffolds evaluated by proliferation of rat's bone marrow mesenchymal stem cells: an in vitro study. Med J Indones 22(4):202-208

81. Karakoti AS, Tsigkou O, Yue S, Lee PD, Stevens MM, Jones JR, Seal S (2010) Rare earth oxides as nanoadditives in 3-D nanocomposite scaffolds for bone regeneration. J Mater Chem 20(40):8912-8919

82. Chen J, Patil S, Seal S, McGinnis JF (2006) Rare earth nanoparticles prevent retinal degeneration induced by intracellular peroxides. Nat Nanotechnol 1(2):142-150

\section{Publisher's Note}

Springer Nature remains neutral with regard to jurisdictional claims in published maps and institutional affiliations.

\section{Submit your manuscript to a SpringerOpen ${ }^{\circ}$ journal and benefit from:}

- Convenient online submission

- Rigorous peer review

- Open access: articles freely available online

- High visibility within the field

- Retaining the copyright to your article

Submit your next manuscript at $\boldsymbol{\nabla}$ springeropen.com 